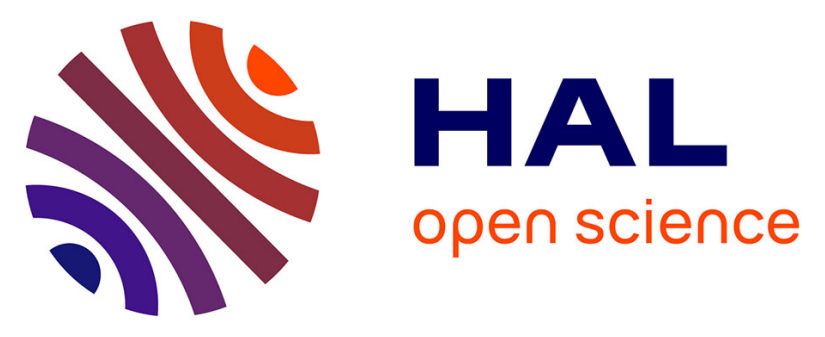

\title{
Mitochondria and calcium flux as targets of neuroprotection caused by minocycline in cerebellar granule cells
}

Eva Maria Garcia-Martinez, Sara Sanz-Blasco, Andonis Karachitos, Miguel J. Bandez, Francisco J. Fernandez-Gomez, Sergio Perez-Alvarez, Raquel Maria Melero Fernandez De Mera, Maria J. Jordan, Norberto Aguirre, Maria F. Galindo, et al.

\section{- To cite this version:}

Eva Maria Garcia-Martinez, Sara Sanz-Blasco, Andonis Karachitos, Miguel J. Bandez, Francisco J. Fernandez-Gomez, et al.. Mitochondria and calcium flux as targets of neuroprotection caused by minocycline in cerebellar granule cells. Biochemical Pharmacology, 2009, 79 (2), pp.239. 10.1016/j.bcp.2009.07.028 . hal-00535821

\section{HAL Id: hal-00535821 \\ https://hal.science/hal-00535821}

Submitted on 13 Nov 2010

HAL is a multi-disciplinary open access archive for the deposit and dissemination of scientific research documents, whether they are published or not. The documents may come from teaching and research institutions in France or abroad, or from public or private research centers.
L'archive ouverte pluridisciplinaire HAL, est destinée au dépôt et à la diffusion de documents scientifiques de niveau recherche, publiés ou non, émanant des établissements d'enseignement et de recherche français ou étrangers, des laboratoires publics ou privés. 


\section{Accepted Manuscript}

Title: Mitochondria and calcium flux as targets of neuroprotection caused by minocycline in cerebellar granule cells

Authors: Eva Maria Garcia-Martinez, Sara Sanz-Blasco, Andonis Karachitos, Miguel J. Bandez, Francisco J.

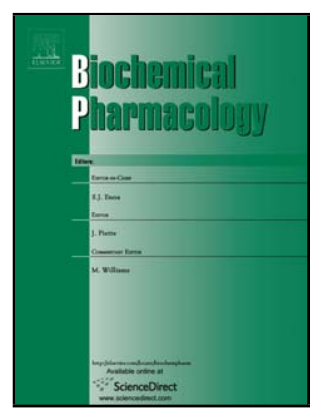

Fernandez-Gomez, Sergio Perez-Alvarez, Raquel Maria

Melero Fernandez de Mera, Maria J. Jordan, Norberto

Aguirre, Maria F. Galindo, Carlos Villalobos, Ana Navarro, Hanna Kmita, Joaquín Jordán

PII:

S0006-2952(09)00685-6

DOI: doi:10.1016/j.bcp.2009.07.028

Reference: BCP 10289

To appear in: $\quad B C P$

Received date: 4-6-2009

Revised date: 29-7-2009

Accepted date: $\quad$ 29-7-2009

Please cite this article as: Garcia-Martinez EM, Sanz-Blasco S, Karachitos A, Bandez MJ, Fernandez-Gomez FJ, Perez-Alvarez S, Mera RMMF, Jordan MJ, Aguirre N, Galindo MF, Villalobos C, Navarro A, Kmita H, Jordán J, Mitochondria and calcium flux as targets of neuroprotection caused by minocycline in cerebellar granule cells, Biochemical Pharmacology (2008), doi:10.1016/j.bcp.2009.07.028

This is a PDF file of an unedited manuscript that has been accepted for publication. As a service to our customers we are providing this early version of the manuscript. The manuscript will undergo copyediting, typesetting, and review of the resulting proof before it is published in its final form. Please note that during the production process errors may be discovered which could affect the content, and all legal disclaimers that apply to the journal pertain. 
Mitochondria and calcium flux as targets of neuroprotection caused by

\section{minocycline in cerebellar granule cells.}

Eva Maria Garcia-Martinez ${ }^{1,2}$ Sara Sanz-Blasco ${ }^{3}$, Andonis Karachitos ${ }^{4}$, Miguel J Bandez $^{5}$, Francisco J Fernandez-Gomez ${ }^{1}$, Sergio Perez-Alvarez ${ }^{1}$, Raquel Maria Melero Fernandez de Mera $^{1}$, Maria J Jordan ${ }^{6}$, Norberto Aguirre ${ }^{7}$, Maria F Galindo ${ }^{8}$, Carlos Villalobos $^{3}$, Ana Navarro ${ }^{5}$, Hanna Kmita ${ }^{4}$, Joaquín Jordán ${ }^{1,9 *}$

${ }^{1}$ Neurofarmacología. Dpto Ciencias Médicas. Facultad de Medicina. UCLM. Spain.

${ }^{2}$ Servicio de Farmacia Hospitalaria. Complejo Hospitalario Universitario de Albacete. Spain. ${ }^{3}$ Instituto de Biología y Genética Molecular (IBGM), Univ. Valladolid-CSIC. Valladolid. Spain. ${ }^{4}$ Laboratory of Bioenergetics, Institute of Molecular Biology and Biotechnology, Faculty of Biology, Adam Mickiewicz University, 61-614 Poznan, Umultowska 89. Poland. ${ }^{5}$ Bioquímica y Biología Molecular, Facultad de Medicina, Univ. Cádiz. Cádiz. Spain. ${ }^{6}$ Instituto Murciano de Investigación y Desarrollo Agrario y Alimentario. La Alberca (Murcia). Spain.

${ }^{7}$ Farmacología, Facultad de Medicina, Univ. Navarra. Pamplona. Spain. ${ }^{8}$ Unidad PfizerCastilla-La Mancha de Neuropsicofarmacología Translacional. Complejo Hospitalario Universitario de Albacete. Spain. ${ }^{9}$ Centro Regional de Investigaciones Biomédicas. UCLM. Albacete. Spain.

\section{Running title: Minocycline modulates mitochondrial functions}

* Corresponding author: Joaquín Jordán, Grupo de Neurofarmacología. Departamento de Ciencias Médicas. Universidad Castilla-La Mancha- Centro Regional de Investigaciones Biomédicas, Avda Almansa 14, Albacete-02006, Spain. Tel.: +34-967-599200. Fax: +34967599327. E-mail: joaquin.jordan@uclm.es 
Abstract

Minocycline, an antibiotic of the tetracycline family, has attracted considerable interest for its theoretical therapeutic applications in neurodegenerative diseases. However, the mechanism of action underlying its effect remains elusive. Here we have studied the effect of minocycline under excitotoxic conditions. Fluorescence and bioluminescence imaging studies in rat cerebellar granular neuron cultures using fura-2/AM and mitochondria-targeted aequorin revealed that minocycline, at concentrations higher than those shown to block inflammation and inflammation-induced neuronal death, inhibited NMDA-induced cytosolic and mitochondrial rises in $\mathrm{Ca}^{2+}$ concentrations in a reversible manner. Moreover, minocycline added in the course of NMDA stimulation decreased $\mathrm{Ca}^{2+}$ intracellular levels, but not when induced by depolarization with a high $\mathrm{K}^{+}$medium. We also found that minocycline, at the same concentrations, partially depolarized mitochondria by about 5-30 mV, prevented mitochondrial $\mathrm{Ca}^{2+}$ uptake under conditions of environmental stress, and abrogated NMDAinduced reactive oxygen species (ROS) formation. Consistently, minocycline also abrogates the rise in ROS induced by $75 \mu \mathrm{M} \mathrm{Ca}^{2+}$ in isolated brain mitochondria. In search for the mechanism of mitochondrial depolarization, we found that minocycline markedly inhibited state 3 respiration of rat brain mitochondria, although distinctly increased oxygen uptake in state 4. Minocycline inhibited NADH-cytochrome $c$ reductase and cytochrome c oxidase activities, whereas the activity of succinate-cytochrome $c$ reductase was not modified, suggesting selective inhibition of complex I and IV. Finally, minocycline affected activity of voltage-dependent anion channel (VDAC) as determined in the reconstituted system. Taken together, our results indicate that mitochondria are a critical factor in minocycline-mediated neuroprotection. 
Key words: anti-oxidant, apoptosis, voltage-dependent anion channel, uncoupler, aequorin, bioluminescence.

Abbreviations: 2,2-diphenyl-1-picrylhydrazyl, DPPH•; 2,4,6-tripyridyl-S-triazine, TPTZ; 5-(and 6-)-chloromethyl-2,7-dichlorodihydrofluorescein diacetate, CM- $\mathrm{H}_{2} \mathrm{DCFDA}$; adenine nucleotide translocase, ANT; amyotrophic lateral sclerosis, ALS; Carbonylcyanide-4(trifluoromethoxy)-phenylhydrazone, FCCP; ferric reducing ability of plasma, FRAP; cytosolic $\mathrm{Ca}^{2+}$ concentrations, $\left[\mathrm{Ca}^{2+}\right]_{\text {cyt }}$; fluorescein diacetate, DFCA; Green Fluorescence protein, GFP; Hydroethidine, Het; mitochondrial $\mathrm{Ca}^{2+}$ concentrations, $\left[\mathrm{Ca}^{2+}\right]_{\mathrm{m}}$; mitochondrial inner membrane potential, $\Delta \Psi \mathrm{m}$; mitochondrial permeability transition pore, MPTP; Nmethyl-D-aspartic acid , NMDA; region of interest, ROI; reactive oxygen species, ROS; superoxide anion radical, $\cdot \mathrm{O}_{2}{ }^{-} ; 2,4,6$-tripyridyl-S-triazine, TPTZ; tetramethylrhodamine methyl ester, TMRM; voltage-dependent anion channel, VDAC. 


\section{Introduction}

Minocycline, a semi-synthetic derivate of tetracycline, is under scientific debate as a potential therapeutic agent in neurological disease processes (for review see $[1,2]$. Support for this new application of a time-tested antibiotic comes from observations that minocycline readily crosses the blood-brain barrier to the greatest extent of all of the tetracyclines and is well tolerated. It affords neuroprotection in experimental models of Parkinson's disease, Huntington's disease, multiple sclerosis, amyotrophic lateral sclerosis (ALS), and acute inflammation after brain trauma or cerebral ischemia [1,3]. Although there are inconsistent reports that show detrimental effects in different models of neurodegeneration $[4,5]$, numerous studies have focused on the mechanisms underlying minocycline-mediated cell protection. However, the possible mechanisms described so far are poorly understood and need to be clarified.

We and others have postulated that mitochondria could be the pharmacological target affected by minocycline to afford cytoprotection. Proton-translocation by components of the respiratory chain generates the mitochondrial inner membrane potential $(\Delta \Psi \mathrm{m})$. This transmembrane potential can be used to phosphorylate ADP to ATP or for $\mathrm{Ca}^{2+}$ uptake into mitochondria [6]. When added to isolated mitochondria, minocycline is able to decrease the $\Delta \Psi \mathrm{m}$, possibly preventing mitochondrial permeability transition pore (MPTP) opening and the subsequent release of cytochrome $c$. Furthermore, $\Delta \Psi \mathrm{m}$ is considered an important factor in the maintenance of mitochondrial homeostasis: both $\mathrm{Ca}^{2+}$ uptake [7] and production of reactive oxygen species (ROS) are attenuated due to a decrease in $\Delta \Psi \mathrm{m}$ [8]. Thus, small changes in $\Delta \Psi \mathrm{m}$ may contribute to the cytoprotection mechanisms. Mitochondrial depolarization, caused by low concentrations of mitochondrial uncouplers, has been shown to be protective against NMDA-induced neuronal death [9]. 
Mounting evidence indicates that ROS-mediated stress plays a major role in the pathogenesis of many neurodegenerative disorders. Accordingly, it has been shown that excitotoxicity, which plays a critical role in several neurological pathologies, promotes significant increases in cytosolic $\mathrm{Ca}^{2+}$ concentrations $\left(\left[\mathrm{Ca}^{2+}\right]_{\text {cyt }}\right)$, ROS production, oxidative damage, and ultimately cell death $[10,11]$. In addition, mitochondrial $\mathrm{Ca}^{2+}$ overload plays a pivotal role in many cell death models including excitotoxicity [11]. Specifically, it has been reported that glutamate-induced neurotoxicity depends on mitochondrial $\mathrm{Ca}^{2+}$ uptake $\left(\left[\mathrm{Ca}^{2+}\right]_{\mathrm{m}}\right)[9,12]$. Under stress conditions, there is an early increase in $\left[\mathrm{Ca}^{2+}\right]_{\mathrm{m}}$ that may contribute to mitochondrial dysfunction $[13,14]$ and MPTP opening, a point-of-no-return step in the intrinsic pathway of apoptotic cell death $[15,16]$.

Nowadays, the molecular composition of the MPTP is still under debate. Numerous independent studies suggest that the MPTP consists of a voltage-dependent anion channel (VDAC) within the outer membrane, and adenine nucleotide translocase (ANT) within the inner membrane. The mechanism of VDAC contribution to MPTP still remains elusive. The available data indicate that pro-apoptotic stimuli can trigger a state of high or low conductance of VDAC. It has also been suggested that anti-apoptotic activity may involve an inhibitory VDAC interaction with MPTP constituents which appears critical for mitochondrial metabolite transport, volume regulation, and apoptosis [for review see, [17-19]. On the other hand, there is also evidence indicating that VDAC participates in signal generation without direct involvement in subsequent processes (e.g. [20]).

Herein, we have designed several experiments to understand the mechanisms responsible for minocycline-mediated neuroprotection under excitotoxic conditions. After NMDA receptor activation, we analyzed minocycline's effect on two of the earliest events which can tip the scales in favour of neurodegeneration. Close attention was paid to the entry of $\mathrm{Ca}^{2+}$ through the plasma membrane, mitochondrial $\mathrm{Ca}^{2+}$ uptake, and generation of ROS. 
Garcia-Martinez EM et al.,

We also studied different parameters describing mitochondrial functions. Our results suggest that minocycline, although at concentrations higher than those shown to block inflammation and inflammation-induced neuronal death [21], prevents NMDA-induced excitotoxicity by diminishing NMDA-induced $\mathrm{Ca}^{2+}$ entry and altering the $\Delta \Psi \mathrm{m}$ via mitochondrial $\mathrm{Ca}^{2+}$ uptake. The latter may be caused by activity changes in VDAC as well as the respiratory chain.

\section{Materials and Methods}

\subsection{Chemicals.}

Fura-2, hydroethidine, $\mathrm{CM}-\mathrm{H}_{2} \mathrm{DCFDA}$, TMRM and celenterazin were obtained from Invitrogen (Barcelona, Spain). Mitochondrial AEQ construct was a gift from Prof. Brulet (Paris, France). Culture media, sera and antibiotics are from Lonza. If not indicated otherwise, all other chemicals were purchased from Sigma or Merck.

\subsection{Animals}

For cerebellar granule cell cultures, 5-7-day-old Wistar rats were used. Brain mitochondria were isolated from 3-month-old male Wistar rats. All animals were housed at 22 $\pm 2{ }^{\circ} \mathrm{C}$ with $12 \mathrm{~h} / 12 \mathrm{~h}$ light/dark cycles and with full access to water and food. Animal experiments were carried out in accordance with the Guiding Principles for Research Involving Animals and Human Beings of the American Physiological Society, the Guidelines of the European Union Council (86/609/CEE), and the Spanish regulations (BOE 67/8509-12, 1988) for the use of laboratory animals. Approval was obtained from the Scientific Committee of the Universities of Cádiz, Castilla-La Mancha, and Valladolid.

\subsection{Cell Cultures}


Cerebellar granule cells were obtained as reported previously [22], plated on poly-Llysine coated, $12 \mathrm{~mm}$ diameter glass coverslips. They were cultured in high-glucose, low $\mathrm{K}^{+}$, Dulbecco's modified Eagle's medium (DMEM, Gibco, Spain) plus 10\% fetal bovine serum, 5\% horse serum, $100 \mu \mathrm{g} / \mathrm{ml}$ penicillin, and $100 \mu \mathrm{g} / \mathrm{ml}$ streptomycin for 2 days. Then the culture medium was replaced by Sato's medium plus 5\% horse serum (to avoid excessive proliferation of glia) and cultured for 2-4 days before experiments.

\subsection{Cell viability studies}

To study NMDA-induced toxicity, neuronal cultures maintained 7 days in vitro were incubated for 30 min with $100 \mu \mathrm{M}$ NMDA, $2 \mu \mathrm{M} \mathrm{Ca}^{2+} / \mathrm{Na}^{+}$and $10 \mu \mathrm{M}$ glycine in saline solution. Treatments were terminated by washing cells three times with Krebs solution before incubating with regular medium. Minocycline was added $10 \mathrm{~min}$ before NMDA at different concentrations and maintained during the whole experiment. Cell viability was analyzed $24 \mathrm{~h}$ later using the fluorescein diacetate/ propidium iodide double-staining procedure. Living and dead cells were counted in 3-4 coverslips per condition (a total of 300-450 cells per coverslip) and normalized to corresponding controls. At least three independent experiments were used for quantification

\subsection{Fluorescence imaging of cytosolic $\left[\mathrm{Ca}^{2+}\right]$}

Coverslips containing cerebellar granule cells were incubated in standard medium containing (in mM) $\mathrm{NaCl} 145, \mathrm{KCl} 5, \mathrm{CaCl}_{2} 1, \mathrm{MgCl}_{2} 1$, glucose 10, Hepes 10 (pH 7.42), and loaded with $4 \mu \mathrm{M}$ fura2/AM for $60 \mathrm{~min}$ at room temperature. Coverslips were then placed on the heated stage of an inverted Zeiss microscope (Axiovert S100 TV), and while continuously perfused with the same pre-warmed standard medium, epi-illuminated alternately at 340 and $380 \mathrm{~nm}$. Light emitted above $520 \mathrm{~nm}$ was recorded with an OrcaER Hamamatsu camera 
Garcia-Martinez EM et al.,

(Hamamtsu Photonics, Hamamatsu, Japan). Pixel-by-pixel ratios of consecutive frames were captured, and $\left[\mathrm{Ca}^{2+}\right]_{\mathrm{cyt}}$ was estimated from these ratios as previously reported[23].

\subsection{Bioluminescence imaging of mitochondrial $\left[\mathrm{Ca}^{2+}\right]$}

Cerebellar granule cells were transfected with plasmids containing GFP-aequorin targeted to mitochondria [24] using a Nucleofector II $^{\circledR}$ device and the VPG-1003 transfection kit (Amaxa Biosystems, Cologne, Germany). After $24 \mathrm{~h}$, cells were incubated for $1 \mathrm{~h}$ with 1 $\mu \mathrm{M}$ coelenterazine, washed, and placed into a perfusion chamber set at $37^{\circ} \mathrm{C}$ under a Zeiss Axiovert S100 TV microscope. They were then perfused at 5-10 $\mathrm{ml} / \mathrm{min}$ with test solutions based on the standard perfusion solution pre-warmed to $37^{\circ} \mathrm{C}$ as described above. At the end of each experiment, cells were permeabilized with $0.1 \mathrm{mM}$ digitonin in $10 \mathrm{mM} \mathrm{CaCl}_{2}$ in order to release all the residual aequorin counts. Bioluminescence images were taken with a Hamamatsu VIM photon counting camera handled with an Argus-20 image processor. Photonic emissions were integrated for $10 \mathrm{~s}$ periods. Photons/cell in each image was quantified using the Hamamatsu Aquacosmos software. Total counts per region of interest (ROI) ranged between $2 \cdot 10^{3}$ and $2 \cdot 10^{5}$, and noise was (mean \pm SD) $1 \pm 1$ counts per second (c.p.s.) per typical cell area (2,000 pixels). Data were first quantified as rates of photoluminescence emission/total c.p.s remaining at each time (\% of remaining counts) and divided by the integration period (L/L $\mathrm{L}_{\text {TOTAL }}$ in $\mathrm{s}^{-1}$ ). Emission values of less than 4 c.p.s were not used for calculations. Calibrations in terms of $\left[\mathrm{Ca}^{2+}\right]_{\text {mit }}$ were performed as previously reported [23]. Briefly, the total luminescence for every ROI was computed by adding up the values of all images. In addition, the following values were registered for every time point $(t)$ : $\mathrm{L}=$ Luminescence emission at time $\mathrm{t}$; Sum $(\mathrm{L})=\Sigma \mathrm{L}$ values from $\mathrm{t}=0$ to $\mathrm{t} ; \mathrm{L}_{\mathrm{TOTAL}}\left(\mathrm{L}_{\mathrm{T} 1}\right)=$ Total luminescence remaining at time $\mathrm{t}=\operatorname{Total}(\mathrm{L})-\operatorname{Sum}(\mathrm{L}) ; \quad \% \quad$ Remaining 
luminescence $=100 x \operatorname{Ltotal} /$ Total $(\mathrm{L})$; and ratio $(\mathrm{R})=\mathrm{L} / \mathrm{L}_{\mathrm{T1}}$. Finally, $\left[\mathrm{Ca}^{2+}\right]$ was calculated using the following algorithm:

$\left[\mathrm{Ca}^{2+}\right]$ (in $\left.\mathrm{M}\right)=\left[\mathrm{R}+\left(\mathrm{R} * \mathrm{~K}_{\mathrm{TR}}\right)+1\right] /\left[\left(\mathrm{K}_{\mathrm{R}}-\left(\mathrm{R} * \mathrm{~K}_{\mathrm{R}}\right)\right]\right.$, where $\left.\left.\mathrm{R}=\mathrm{L} / \mathrm{L}_{\mathrm{T} 1} * \lambda\right)\right]^{(1 / \mathrm{n})}$, using the constant values $\mathrm{K}_{\mathrm{R}}, \mathrm{K}_{\mathrm{TR}}, \mathrm{n}$ and $\lambda$ reported previously (see 54 for a detailed description). In some experiments, cells were permeabilized with $20 \mu \mathrm{M}$ digitonin in "intracellular" medium with the following composition: $130 \mathrm{mM} \mathrm{KCl}, 10 \mathrm{mM} \mathrm{NaCl}, 1 \mathrm{mM} \mathrm{MgCl}_{2}, 1 \mathrm{mM} \mathrm{K}_{3} \mathrm{PO}_{4}, 0,2$ mM EGTA, 1 mM ATP, $20 \mu \mathrm{M}$ ADP, 2 mM succinate, 20 mM HEPES/KOH, pH 6.8. Cells were then incubated for 5 min with the same medium containing $200 \mathrm{nM} \mathrm{Ca}^{2+}$ (buffered with EGTA), with or without minocycline. Finally, perfusion was switched to "intracellular" medium containing $5 \mu \mathrm{M} \mathrm{Ca}^{2+}$, with or without minocycline.

\subsection{Mitochondrial potential}

The effects of treatment on $\Delta \Psi$ in intact cerebellar granule cells were estimated by fluorescence imaging of cells loaded with the $\Delta \Psi$ sensitive probe tetramethylrhodamine methyl ester (TMRM), one the most sensitive probes available [25]. Briefly, cerebellar granule cells were loaded with $10 \mathrm{nM}$ TMRM for $10 \mathrm{~min}$, washed with a standard, external medium, and placed on the perfusion chamber of a Zeiss Axiovert S100 TV inverted microscope. Cells were then continuously perfused with pre-warmed $\left(37^{\circ} \mathrm{C}\right)$ external medium, with and without treatments. Fluorescence images were taken at $10 \mathrm{~s}$ intervals with a Hamamatsu VIM photon counting camera handled with an Argus-20 image processor. Traces from individual cells were normalized relative to the value before the addition of either vehicle or treatment and averaged. Background fluorescence after collapse of the mitochondrial potential induced by $10 \mu \mathrm{M}$ FCCP was subtracted. Further details have been reported previously [26]. 


\subsection{Superoxide intracellular production}

Superoxide production was monitored using hydroethidine (HEt, Molecular Probes) as described previously [27]. Coverslips containing cerebellar granule cells were incubated in standard medium containing (in $\mathrm{mM}$ ): $\mathrm{NaCl} 145, \mathrm{KCl} 5, \mathrm{CaCl}_{2} 1, \mathrm{MgCl}_{2} 1$, glucose 10 , and Hepes $10(\mathrm{pH} \mathrm{7.42)}$ and loaded with $10 \mu \mathrm{M}$ hydroethidine. Next, coverslips were placed on the heated stage of an inverted Nikon (Eclipse TE2000) microscope. Light emitted above 535 $\mathrm{nm}$ was recorded with an emission filter of $635 \mathrm{~nm}$ (Omega Optical) with an OrcaER Hamamatsu camera (Hamamatsu Photonics, Hamamatsu, Japan). Background was subtracted. Frames were recorded every $10 \mathrm{~s}$ over a $7 \mathrm{~min}$ period. Linear regression of fluorescence data was obtained of each condition and the slope of the best fitting line was taken as an index of superoxide anion radical $\left(\cdot \mathrm{O}_{2}^{-}\right)$production.

\subsection{Isolation of mitochondria and preparation of mitochondrial membranes}

Brain mitochondria were isolated from the whole rat brain in a small Potter homogenizer with a Teflon pestle. Homogenization was carried out in a medium of $230 \mathrm{mM}$ mannitol, $70 \mathrm{mM}$ sucrose, $1.0 \mathrm{mM}$ EDTA, and $10 \mathrm{mM}$ Tris- $\mathrm{HCl}, \mathrm{pH} 7.40$, at a ratio of $9 \mathrm{ml}$ of homogenization medium/g of tissue. The homogenate was centrifuged at $700 \mathrm{~g}$ for $10 \mathrm{~min}$ and the supernatant at $8,000 \mathrm{~g}$ for $10 \mathrm{~min}$ to precipitate mitochondria that were washed in the same conditions [28]. The obtained mitochondrial suspensions of about $20 \mathrm{mg}$ protein/ml were used immediately after isolation for the determination of respiration or frozen in liquid $\mathrm{N}_{2}$ and kept at $-80^{\circ} \mathrm{C}$. Sub-mitochondrial membranes (disrupted mitochondria) were obtained from brain mitochondria that were twice frozen-and-thawed and homogenized each time by passage through a tuberculin needle. The procedure yielded a preparation of disrupted mitochondria with $0.20-0.24 \mathrm{nmol}$ cytochrome $a a_{3} / \mathrm{mg}$ protein, subsequently used for the determination of enzymatic activity of the respiratory complexes and the presence of markers 
Garcia-Martinez EM et al.,

of oxidative damage. The protein content of the samples was determined using Folin reagent and bovine serum albumin as the standard. To study the effects of minocycline, the braincoupled mitochondria or sub-mitochondrial membranes were added or incubated for 5 min at $4^{\circ} \mathrm{C}$, respectively, with $0,75,100,125$, or $150 \mu \mathrm{M}$ minocycline.

\subsection{Mitochondrial oxygen uptake}

The oxygen uptake of rat brain mitochondria $(0.7-0.8 \mathrm{mg} / \mathrm{ml})$ was determined with a Clark electrode in a $1.5 \mathrm{ml}$ chamber at $30^{\circ} \mathrm{C}$, in an air-saturated reaction medium consisting of: $0.23 \mathrm{M}$ mannitol, $0.07 \mathrm{M}$ sucrose, $20 \mathrm{mM}$ Tris- $\mathrm{HCl}, 1 \mathrm{mM}$ EDTA, $5 \mathrm{mM}$ phosphate, 4 $\mathrm{mM} \mathrm{MgCl} 2$, at $\mathrm{pH}$ 7.4. Respiration rates were determined with $5 \mathrm{mM}$ malate- $5 \mathrm{mM}$ glutamate or $6 \mathrm{mM}$ succinate as substrates, and state 3 respiration was established by addition of 0.5 mM ADP. Mitochondria oxygen uptake was assayed in uncoupled mitochondria with $1 \mu \mathrm{M}$ FCCP. Three determinations were performed for each value.

\subsection{Measurement of ROS levels in mitochondrial suspension}

Mitochondrial ROS production was evaluated with the fluorescent probe 5-(and 6-)chloromethyl-2,7-dichlorodihydrofluorescein diacetate $\left(\mathrm{CM}-\mathrm{H}_{2}\right.$ DCFDA $)$ in isolated mitochondrial suspension. $\mathrm{CM}-\mathrm{H}_{2} \mathrm{DCFDA}$ is a reduced form of fluorescein diacetate (DFCA) that requires oxidation before becoming fluorescent. Therefore, any measurable change in fluorescence intensity can be directly related to changes in free radical activity, mainly the generation of hydrogen peroxide and hydroxyl radicals. Mitochondrial suspensions were incubated with $\mathrm{CM}-\mathrm{H}_{2}$ DCFDA $(10 \mu \mathrm{g} / \mathrm{ml})$, and fluorescence intensity was measured in a Spectra Max Gemini XS (Molecular Devices, Sunnyvale, CA). Brain mitochondria were challenged with $75 \mu \mathrm{M} \mathrm{Ca}^{2+}$ to induce of ROS formation during 30 min with or without minocycline. Experiments were performed in 96-multiwell plates including four samples for 
Garcia-Martinez EM et al.,

each experimental point. The average of relative DFCA fluorescence from at least three

separate mitochondrial preparations was determined. Results are expressed as mean \pm SEM values.

\subsection{Mitochondrial electron transfer activity}

The enzymatic activity of Complexes I-III, II-III, and IV were determined spectrophotometrically at $30^{\circ} \mathrm{C}$ with sub-mitochondrial membranes suspended in $60 \mathrm{mM}$ phosphate buffer ( $\mathrm{pH}$ 7.4) with corresponding substrates added. For NADH-cytochrome c reductase (the activity of complexes I and III) and succinate-cytochrome c reductase (the activity of complexes II and III), mitochondrial membranes were added with $0.20 \mathrm{mM}$ NADH or $5.0 \mathrm{mM}$ succinate as substrates, $0.10 \mathrm{mM}$ cytochrome $\mathrm{c}^{3+}$, and $1.0 \mathrm{mM} \mathrm{KCN}$. The enzymatic activity determined at $550 \mathrm{~nm}\left(\varepsilon=19 \mathrm{mM}^{-1} \mathrm{~cm}^{-1}\right)$, with the results expressed as nmol cytochrome $\mathrm{c}$ reduced / $\min \times \mathrm{mg}$ protein. Cytochrome oxidase (complex IV) was determined in the same buffer with $0.05 \mathrm{mM}$ cytochrome $\mathrm{c}^{2+}$ added, prepared by reduction with ascorbate, and filtration across a Sephadex G25 column. The rate of cytochrome c oxidation was calculated as the first order reaction constant $\left(\mathrm{k}^{\prime}\right)$ per mg protein, and expressed as nmol cytochrome $\mathrm{c}$ oxidized at $10 \mu \mathrm{M}$ cytochrome $\mathrm{c} / \mathrm{min} \times \mathrm{mg}$ protein. This result determines the electron transfer rates of physiological respiration [29]. Three determinations for each value.

\subsection{DPPH radical-scavenging activity}

The scavenging activity of minocycline was measured according to the method described by Brand-Williams et al. [30] with some modifications. Briefly, $500 \mu$ of minocycline methanolic solutions $(100 \mu \mathrm{M})$ at different concentrations $(12.5$ to $150 \mu \mathrm{l} / \mathrm{ml})$ were added to $1 \mathrm{~mL}$ of 2,2-diphenyl-1-picrylhydrazyl (DPPH•) methanolic solution $(0.1 \mathrm{mM})$. 
Garcia-Martinez EM et al.,

Estimated time of reaction (20 min) was determined considering the reduction of absorbance at $517 \mathrm{~nm}$ (monitored every 5 minutes) until the reaction curve reached a plateau. The absorbance was measured at room temperature, in darkness, with a blank (500 $\mu 1$ of sample plus $1 \mathrm{ml}$ of methanol). The absorbance of the control (500 $\mu \mathrm{l}$ of methanol in $1 \mathrm{ml}$ of DPPH• solution) was measured daily. All of the assays were conducted in triplicate. The percentage activity for the $\mathrm{DPPH} \cdot$ technique was calculated according to $\%$ discoloration $=[1-(\mathrm{Abs}$ sample/Abs control)] x 100.

\subsection{Ferric reducing ability assay}

The ferric reducing ability of minocycline was measured according to the method developed by Benzie and Strain (1996) [31]. Antioxidant compounds are able to reduce ferric compounds to ferrous-TPTZ, which develops a blue color with a maximum absorption at 593 nm. FRAP reagent was freshly prepared from $300 \mathrm{mM}$ acetate buffer (pH 3.6), $10 \mathrm{mM}$ 2,4,6tripyridyl-S-triazine (TPTZ) made up in $40 \mathrm{mM} \mathrm{HCl}$, and $20 \mathrm{mM} \mathrm{FeCl} l_{3} \cdot 6 \mathrm{H}_{2} \mathrm{O}$ solution. All three solutions were mixed together in the ratio of 10:1:1(v/v/v). An aliquot of $40 \mu \mathrm{l}$ of minocycline was added to $1.2 \mathrm{ml}$ of FRAP reagent. The absorption of the reaction mixture was measured at $593 \mathrm{~nm}$ after 2 min of incubation at $37^{\circ} \mathrm{C}$. Measurements were performed in triplicate. Fresh working solutions of known Fe (II) concentrations $\left(\mathrm{FeSO}_{4} \cdot 7 \mathrm{H}_{2} \mathrm{O}, 0-2 \mathrm{mM}\right)$ were used for calibration. The antioxidant capacity, based upon the ability to reduce ferric ions of each sample, was calculated from the linear calibration curve and expressed as mmol $\mathrm{FeSO}_{4}$ equivalents.

\subsection{Isolation of VDAC from Saccharomyces cerevisiae mitochondria}


The yeast Saccharomyces cerevisiae M3 cells (MAT $\alpha$, lys2, his4, trp1, ade2, leu2, ura3) [32] were grown at $28^{\circ} \mathrm{C}$ in YPG medium (1\% yeast extract, $2 \%$ peptone, $3 \%$ glycerol) at $\mathrm{pH} 5.5$ to $\mathrm{OD}_{546}$ of 2.2. Mitochondria and the mitochondrial outer membrane were isolated according to the published procedure [33]. The obtained outer membrane pellet was suspended in the solubilization buffer containing 3\% Triton $\mathrm{X}-100,10 \mathrm{mM}$ Tris- $\mathrm{HCl}(\mathrm{pH}$ 7.0), and $1 \mathrm{mM}$ EGTA, incubated for $30 \mathrm{~min}$ at $0^{\circ} \mathrm{C}$. The suspension was then loaded onto a dry hydroxyapatite/celite column [34] and the first two fractions were collected. Before reconstitution, the preparations of VDAC were checked by Western blotting with anti-yeast anti-serum for the presence of marker proteins of mitochondrial compartments as well as for VDAC (not shown).

\subsection{Conductance measurements in planar phospholipid membranes}

Membranes were formed from soybean asolectin suspended at concentration of 25 $\mathrm{mg} / \mathrm{mL}$ in $\mathrm{n}$-decane, across a circular hole (aperture diameter about $250 \mu \mathrm{m}$ ) in the thin wall of a Delrin chamber (Warner Instruments) separating two compartments (cis-trans) filled with unbuffered $1 \mathrm{M} \mathrm{KCl}, \mathrm{pH}$ 7.0. The chamber was connected to the recording equipment through a matched pair of $\mathrm{Ag}-\mathrm{AgCl}$ electrodes. Preparations of VDAC were added in small aliquots $(2-3 \mu \mathrm{l})$ to the cis compartment. Cis also refers to the compartment where the voltage was held. Signals were amplified by a BLM-120 bilayer amplifier (Bio-LOGIC Science Instruments) and computer software was used for data collection. The average amount of analyzed insertion events for a given set of conditions was 70 .

\subsection{Statistics}


When only two means were compared, Student's t test was used. For more than two groups, statistical significance of the data was assessed by analysis of the variance (ANOVA) and compared using Turkey's test. Differences were considered significant at $p<0.05$. For the conductance measurements in planar phospholipid membranes, the differences between calculated values of average conductance were tested by $t$-test (at $\alpha=0.01$ ) for statistical significance.

\section{Results}

\subsection{Minocycline and cell viability}

Consistent with previous data from our laboratory and elsewhere, minocycline afforded cytoprotection to neuronal cultures when exposed to excitotoxic conditions. Cerebellar granular cells were treated with minocycline at different concentrations (1-150 $\mu \mathrm{M})$ and challenged with NMDA $(100 \mu \mathrm{M})$ during 30 min. Twenty four hours later, neuronal viability was evaluated by using fluorescein diacetate and the propidium iodide staining method. As shown in Fig. 1, NMDA treatment decreased cell viability by about 35\% $(\mathrm{p}<0.05)$. Pre-treatment with minocycline, which did not affect cell viability (Figure 1, black bars), afforded neuroprotection in a concentration-dependent manner. Concentrations lower than $50 \mu \mathrm{M}$ did not significantly modify NMDA-induced cell death (Fig. 1).

\subsection{Minocycline and calcium signals}

It has been clearly established that NMDA-induced cell death depends on $\mathrm{Ca}^{2+}$ entry through the plasma membrane and mitochondrial $\mathrm{Ca}^{2+}$ uptake [12]. We therefore studied the effects of minocycline on NMDA induced increases in cytosolic $\left(\left[\mathrm{Ca}^{2+}\right]_{\mathrm{cyt}}\right)$ and mitochondrial $\mathrm{Ca}^{2+}\left(\left[\mathrm{Ca}^{2+}\right]_{\text {mit }}\right)$ concentrations in cerebellar granule cells. Fig. 2A shows pseudocolor images of a representative microscopic field corresponding to $\left[\mathrm{Ca}^{2+}\right]_{\mathrm{cyt}}$ levels during perfusion with 
the glutamate receptor agonist NMDA $(100 \mu \mathrm{M})$ in the presence of minocycline $(100 \mu \mathrm{M})$ and after its removal. We found that in the presence of $100 \mu \mathrm{M}$ minocycline, NMDA induced a rather modest increase in $\left[\mathrm{Ca}^{2+}\right]_{\text {cyt. }}$ Five min after minocycline withdrawal, cells were stimulated again with NMDA and $\left[\mathrm{Ca}^{2+}\right]_{\text {cyt }}$ was monitored. Under these experimental conditions, NMDA increased $\left[\mathrm{Ca}^{2+}\right]_{\text {cyt }}$ to a much larger extent $(\mathrm{p}<0.001, \mathrm{n}=4)$ indicating that minocycline inhibits $\mathrm{Ca}^{2+}$ entry to cells mediated by activation of NMDA receptor channel (Fig. 2A). This result is consistent with our previous findings that minocycline decreases the amplitude and the number of excitatory postsynaptic currents with $\mathrm{EC}_{50}$ between 42 and 64 $\mu \mathrm{M}$, indicating that glutamatergic synaptic transmission is drastically affected by neuroprotective concentrations of minocycline (30 $\mu \mathrm{M}$ or higher [35]).

To study the effects of minocycline on $\left[\mathrm{Ca}^{2+}\right]_{\text {mit }}$ cerebellar granule cells were transfected with mitochondria-targeted aequorin, a bioluminescent probe widely used for subcellular $\mathrm{Ca}^{2+}$ measurements $[22,23]$. This probe also contains GFP to help selecting transfected cells for bioluminescence imaging. Cerebellar granule cells were transfected with the GA plasmid and incubated for $24 \mathrm{~h}$ to allow for the expression of the $\mathrm{Ca}^{2+}$ probe. Fig. 2B shows the bioluminescence (AEQ) and fluorescence (GFP) images of transfected cerebellar granule cells. We found that NMDA, in the presence of $100 \mu \mathrm{M}$ minocycline, failed to induce any rise in $\left[\mathrm{Ca}^{2+}\right]_{\mathrm{mit}}$. However, after removal of minocycline, NMDA promoted the increase in $\left[\mathrm{Ca}^{2+}\right]_{\text {mit }}(\mathrm{n}=2)$. Thus, these results indicate that minocycline inhibits both the cytosolic and the mitochondrial rises in $\mathrm{Ca}^{2+}$ concentrations induced by NMDA in a reversible manner.

To address whether minocycline inhibits the increase in $\left[\mathrm{Ca}^{2+}\right]_{c y t}$ in a specific manner, we studied the effects of minocycline on $\left[\mathrm{Ca}^{2+}\right]_{c y t}$ induced by either NMDA or high $\mathrm{K}^{+}$ medium, added here to promote opening of voltage-gated $\mathrm{Ca}^{2+}$ channels. Fig. 3 shows that minocycline blocked NMDA-induced $\left[\mathrm{Ca}^{2+}\right]_{\text {cyt }}$ rise but failed to reduce the increased $\left[\mathrm{Ca}^{2+}\right]_{\text {cyt }}$ induced by a high- $\mathrm{K}^{+}$medium. Traces are Mean \pm SEM values of all cells present in 
representative experiments. These data indicate that minocycline does not inhibit voltagegated $\mathrm{Ca}^{2+}$ channels that can be activated by NMDA-induced plasma membrane depolarization.

In the next set of experiments we studied whether minocycline may affect the mitochondrial inner membrane potential and mitochondrial $\mathrm{Ca}^{2+}$ uptake acting on intact cells. Cerebellar granule cells were loaded with the mitochondrial inner membrane potential probe TMRM and subjected to fluorescence microscopy. Fig. 4A shows TMRM staining of cerebellar granule cells before and after the addition of $100 \mu \mathrm{M}$ minocycline. An image of the same cells after adding the mitochondrial uncoupler FCCP is also shown. Perfusion of TMRM-loaded cells with minocycline induced a dose-dependent decrease in TMRM fluorescence consistent with a mitochondrial depolarization. This effect was absent at $1 \mu \mathrm{M}$ minocycline (not shown), slightly apparent at $10 \mu \mathrm{M}$ and quite strong at $100 \mu \mathrm{M}$. As expected, the mitochondria uncoupler FCCP $(10 \mu \mathrm{M})$ caused organelle depolarization (Fig. 4A). Therefore, these results indicate that minocycline depolarizes mitochondria in intact cells in a dose-dependent manner. Minocycline decreases TMRM fluorescence at 10 and $100 \mu \mathrm{M}$ by $17 \pm 4$ and $70 \pm 6 \%$ respectively, relative to the effect of the total uncoupler FCCP at $10 \mu \mathrm{M}$. We have shown previously that decreases in TMRM can be used to estimate mitochondrial potential decrements [12]. According to the algorithm proposed [12], we estimate that minocycline, at 10-100 $\mu \mathrm{M}$, depolarizes mitochondria in intact cerebellar granule cells by 5$30 \mathrm{mV}$.

We have reported recently that a weak depolarization of mitochondria may largely influence mitochondrial $\mathrm{Ca}^{2+}$ uptake [23]. Accordingly, we studied whether minocycline inhibited mitochondrial $\mathrm{Ca}^{2+}$ uptake in permeabilized cells exposed to $\mathrm{Ca}^{2+}$ concentrations similar to those achieved in $\mathrm{Ca}^{2+}$ microdomains $(10 \mu \mathrm{M})$. Cerebellar granule cells were transfected with the GA plasmid and incubated for $24 \mathrm{~h}$. Then cells were incubated with 
digitonin and subjected to bioluminescence imaging. Fig. 4B shows that addition of $\mathrm{Ca}^{2+}$ to permeabilized cells in the presence of $100 \mu \mathrm{M}$ minocycline failed to rise $\left[\mathrm{Ca}^{2+}\right]_{\text {mit. }}$ After removal of minocycline, addition of $\mathrm{Ca}^{2+}$ induced release of photonic emissions corresponding to a increase in $\left[\mathrm{Ca}^{2+}\right]_{\mathrm{mit}}$ ( $\mathrm{n}=36$ cells, 6 independent experiments). Therefore, these results indicate that minocycline induces mitochondrial depolarization to such an extent that inhibits mitochondrial $\mathrm{Ca}^{2+}$ uptake.

\subsection{Minocycline and ROS production}

Increasing amount of data indicates that ROS play a major role in the pathogenesis of neurodegenerative disorders [16] and also in excitotoxic cell death models [36]. As shown in Fig. 5A, cerebellar granular neurons challenged with NMDA $(100 \mu \mathrm{M})$ showed a higher rate of oxidation of dihydroethidine, an indicator of superoxide anion production. Specifically, cerebellar granular neurons presented a basal superoxide production rate of $0.019 \pm 0.0023$ A.F.U./min ( $\mathrm{n}=78)$. The addition of NMDA $(100 \mu \mathrm{M})$ induced an increase in the rate of superoxide production, to a value of $4.18 \pm 0.9645$ A.F.U./min $(n=186)$. The effect that was abrogated by minocycline in a concentration-dependent manner.

In order to ascertain whether minocycline blocked ROS production at the mitochondrial level, we used $\mathrm{CM}-\mathrm{H}_{2}$ DCFDA to measure peroxide-like formation in brain isolated mitochondria challenged with high $\mathrm{Ca}^{2+}$. First, minocycline decreased basal mitochondrial ROS production (Fig. 5B). The addition of $75 \mu \mathrm{M} \mathrm{Ca}^{2+}$ to the mitochondrial suspension resulted in a significant increase in the production of ROS (2.8 fold increase). Minocycline inhibited this increase (Fig. 5B). In addition, the mitochondrial uncoupler FCCP $(10 \mu \mathrm{M})$ was also able to inhibit the increase in ROS production induced by the applied concentration of $\mathrm{Ca}^{2+}$ (Fig. 5B). 
Taking into account these results, we went further to explore whether minocycline might function as a superoxide dismutase (SOD) or a catalase mimetic in a cell free system. Our results revealed that minocycline does not show any of the above mentioned enzymatic activities (data not shown). Interestingly, and consistent with previous data, minocycline showed a diphenylpicrylhydrazyl (DPPH) radical scavenger activity [37], an effect that reached statistical significance at a concentration of $25 \mu \mathrm{M}$ and above (Fig. 5C). Furthermore, our data also confirmed that minocycline mediated the reduction of $\mathrm{Fe}^{3+}$ to $\mathrm{Fe}^{2+}$, at concentrations higher than $10 \mu \mathrm{M}$ (Fig. 5D).

\subsection{Minocycline-induced effects on mitochondrial function}

The $\mathrm{O}_{2}$ uptake of isolated rat brain mitochondria was determined in resting state, in phosphorylating state and in uncoupled state triggered by FCCP. Malate-glutamate and succinate were used as respiratory substrates in the presence of minocycline in the range of 75-125 $\mu$ M. Fig. 6 and 7 present typical recordings of the oxygen uptake obtained in the presence of $125 \mu \mathrm{M}$ minocycline for phosphorylating state (Fig. 6) and resting and uncoupled states (Fig. 7). Minocycline increased the oxygen uptake in resting state, by about $80 \%$ in the case of malate-glutamate as respiratory substrate and by about $60 \%$ with succinate as respiratory substrate but simultaneously decreased the uncoupling capacity of FCCP by about $50 \%$ for the both respiratory substrates. However, in phosphorylating state minocycline caused decrease in oxygen uptake, by about $60 \%$ in the case of malate-glutamate as respiratory substrate and by about $50 \%$ with succinate as respiratory substrate. The effect of minocycline on the oxygen uptake by brain mitochondria in uncoupled state in the presence of malate-glutamate and succinate as respiratory substrates were similar to that observed for phosphorylating state and the calculated levels of inhibition were about 50 and $45 \%$ respectively. The inhibition was not caused by minocycline-mediated rupture of the 
Garcia-Martinez EM et al.,

mitochondrial outer membrane as minocycline did not cause increase in cytochrome c release

(not shown). Fig. 8 summarizes the effect of different concentrations of minocycline on the oxygen uptake during the studied respiratory states. Independently of the studied respiratory substrate we observed minocycline-concentration dependent inhibition of phosphorylating and uncoupled states and stimulation of resting state. However, the obtained calibration curves differed in shape between malate-glutamate and succinate that suggests differences of the applied mechanisms. Therefore we analyzed the influence of minocycline on enzymatic activities of the respiratory chain complexes I+III (NADH-cytochrome c reductase), II+III (succinate-cytochrome c reductase), and IV (cytochrome c oxidase). As shown in Fig. 9, minocycline in the range of $75-150 \mu \mathrm{M}$ inhibited markedly complexes I+III and IV. Thus minocycline appeared to affect the oxygen uptake supported by malate-glutamate at the level of complexes I and IV and the oxygen uptake supported by succinate only at the level of complex IV.

\subsection{Minocycline affects VDAC conductance and voltage dependence}

There is a growing amount of data showing that the voltage dependent anion channel (VDAC) is a dynamic regulator, or governor, of mitochondrial functions (for review see [17, 18]. Therefore we have studied the effects of minocycline on channel-forming activity of VDAC reconstituted into lipid bilayers. It was achieved by adding VDAC preparation to the aqueous phase of one side (so called cis side) of a black membrane bilayer made of asolectin. It is well known that VDAC behavior in planar phospholipid membranes made of asolectin is voltage dependent and symmetrical [38-40], meaning that the channel closes at about the same rate and to about the same extent depending on the applied potential value but regardless its sign. Thus, VDAC reconstituted into planar phospholipid membranes displays the ability to adopt a fully open state and multiple closed states of significantly smaller 
Garcia-Martinez EM et al.,

conductance that differ in permeability. The VDAC protein was isolated from mitochondria of the yeast Saccharomyces cerevisiae that contain only one channel-forming VDAC isoform [41] and are commonly used as a model to study mitochondrial biology. Since $100 \mu \mathrm{M}$ minocycline did not change formation and stability of the planar phospholipid membrane, we perform comparative experiments at different values of the applied positive and negative potential and in the presence of different concentrations of minocycline. The obtained distributions of conductances in $1 \mathrm{M} \mathrm{KCl}$ were used to build histograms and to calculate values of average conductance of VDAC under a given experimental conditions.

The effect imposed by minocycline on VDAC conductance did not depend on the sign of the applied potential and was clearly visible under conditions of the dominance of VDAC fully open state, i.e. at a membrane potential of $10 \mathrm{mV}$. Examples of single channel insertions at a membrane potential of $+10 \mathrm{mV}$ shown in Fig. $\mathbf{1 0 A}$ indicate that unexpectedly minocycline caused flickering of VDAC conductance in the second or even millisecond time scale dependently of minocycline concentration. Single channel insertions were then used to create histograms. Fig. 10B presents histograms obtained at $+10 \mathrm{mV}$ and in the presence of increasing concentrations of minocycline. Addition of minocycline distinctly changed distribution of VDAC conductance and consequently caused decrease in calculated values of average conductance dependently of its concentration (Fig. 10C). The calculated values of average conductance at $+10 \mathrm{mV}$ were as follows (in $\mathrm{nS}$ ): $3.9 \pm 0.1 \mathrm{nS}$ (in the absence of minocycline), $3.4 \pm 0.3(10 \mu \mathrm{M}$ minocycline $), 3.2 \pm 0.4$ (50 $\mu \mathrm{M}$ minocycline) and $2.9 \pm 0.4$ (100 $\mu \mathrm{M}$ minocycline). This denotes a serious change in a functional state of VDAC towards lower conductance states as the dominance of VDAC closure observed at $+70 \mathrm{mV}$ corresponded to an average conductance of $1.9 \pm 0.2 \mathrm{nS}$. The observed effect imposed by minocycline on VDAC conductance could result from changes in voltage dependence of the channel. Voltage dependence can be observed in reconstitution systems and is defined as the 
Garcia-Martinez EM et al.,

probability of a channel occurrence in a given conductance state depending on the value of the applied potential [32, 42]. As shown in Fig. 10D, in the absence as well as in the presence of minocycline an increase in the value of the applied potential facilitated closure of the studied channels that resulted in a decrease of the value of an average conductance calculated for a given potential $(G)$. This, in turn, caused a decrease in the value of the ratio $G / G_{o}$, where $G_{o}$ denotes an average conductance at the lowest applied potential $(10 \mathrm{mV})$. The sign of the applied potential did not influence these changes. However, in the presence of minocycline the VDAC voltage dependence was less pronounced and the weakening was concentrationdependent.

\section{Discussion}

The present data, built upon our group's previous work [22, 35, 43], posits the intricate involvement of mitochondria in minocycline-mediated cytoprotection for neuronal cells. Following excitotoxic NMDA receptor activation, the accumulation of $\mathrm{Ca}^{2+}$ and the generation of ROS are modulated as minocycline targets mitochondria. Intervention with minocycline may prove useful as these are two events that occur early in neurodegenerative processes.

Consistent with previous observations [44, 45], minocycline afforded cytoprotection to neuronal cultures under conditions of NMDA receptor-mediated excitotoxicity, although at a concentration range higher than that needed to block inflammation and inflammation-induced neuronal death [21]. In cultures pre-treated with minocycline, the NMDA-induced $\left[\mathrm{Ca}^{2+}\right]_{\mathrm{cyt}}$ rise was dramatically inhibited. We can exclude this effect as a consequence of the well established association between tetracyclines and $\mathrm{Ca}^{2+}$ buffer capacity [43]. Minocycline failed to modify the intracellular levels of $\mathrm{Ca}^{2+}$ in resting conditions, and did not attenuate a $\mathrm{Ca}^{2+}$ increase following cellular depolarization with $50 \mathrm{mM} \mathrm{KCl}$. Our data also revealed that 
this effect was reversible, demonstrated when minocycline removal allowed neurons to respond to NMDA in a similar extent as control cell cultures. Furthermore, minocycline actually decreased $\left[\mathrm{Ca}^{2+}\right]_{\text {cyt }}$ during the course of NMDA receptor stimulation. This later result might explain recent studies showing minocycline blocking centrally mediated hyperalgesia induced by intrathecal NMDA [46], or shed some light on the favourable effects of minocycline in a therapeutic window between 6 and 24 hours after a stroke [47].

Minocycline does more than just preventing $\mathrm{Ca}^{2+}$ fluxes at the plasma membrane. It also reduced $\left[\mathrm{Ca}^{2+}\right]_{\text {mit }}$ overload, a pivotal role in excitotoxicity and other models of cell death $[9,12,15]$. By using bioluminescence imaging with mitochondria-targeted aequorin, we directly observed the effects of minocycline on NMDA-induced mitochondrial $\mathrm{Ca}^{2+}$ overload. This effect remained in permeabilized cells as minocycline abrogated mitochondrial $\mathrm{Ca}^{2+}$ uptake induced by $\mathrm{Ca}^{2+}$ concentrations that surpass the activation of the mitochondrial $\mathrm{Ca}^{2+}$ uniporter. Supporting the hypothesis that small changes in mitochondrial potential may dramatically influence mitochondrial $\mathrm{Ca}^{2+}$ uptake, minocycline, at $100 \mu \mathrm{M}$, decreased by about $5-30 \mathrm{mV}$ the $\Delta \Psi \mathrm{m}$ in cerebellar granular cells. Therefore, minocycline reduces the electrochemical driving force required for mitochondrial $\mathrm{Ca}^{2+}$ uptake, resulting in the prevention of $\left[\mathrm{Ca}^{2+}\right]_{\text {mit }}$ overload in excitotoxicity. Accordingly, prevention of mitochondrial $\mathrm{Ca}^{2+}$ uptake by the mitochondrial $\mathrm{Ca}^{2+}$ uncoupler FCCP largely abrogated NMDA-induced cell death [9]. Therefore, minocycline inhibit mitochondrial $\mathrm{Ca}^{2+}$ overload induced by NMDA acting both at the plasma membrane level and at the mitochondrial level. These two actions seem independent as FCCP does not prevent NMDA-induced $\mathrm{Ca}^{2+}$ influx (data not shown).

Minocycline also weakened ROS production, both in cultured neurons and in isolated mitochondria. Minocycline reduced the rate of increase of hydroethidine oxidation in neurons exposed to NMDA. Minocycline also reduced peroxide-like generation in isolated mitochondria suspensions when challenged with $75 \mu \mathrm{M} \mathrm{Ca}^{2+}$. Similar to minocycline's effect 
on $\Delta \Psi \mathrm{m}$, this anti-oxidant action was mimicked by the mitochondrial uncoupler FCCP. We can not exclude a structure-dependent anti-oxidant effect of minocycline, since previous findings [48] have shown a direct DPPH radical scavenging property and the capacity to reduce $\mathrm{Fe}^{3+}$. However, such properties failed to afford SOD or catalase activity of minocycline. We have previously shown that minocycline does not prevent malonate-induced peroxide formation in cerebellar granular cell [22], and is unable to prevent ROS-mediated MPTP opening that supporting the above statement [43].

Consistent with a role of mitochondria as a target of minocycline-mediated neuroprotection, we found that minocycline affects distinctly activity of the respiratory chain although the observed effect is rather complicated.. First, minocycline inhibits complex I and complex IV of the respiratory chain. Interestingly, only these two complexes are true proton pumps within the respiratory chain able to physically move protons across a membrane [49]. Nevertheless, the observed inhibition occurs in phosphorylating and uncoupled states supported by malate-glutamate or by succinate. On the other hand, the inhibition limits uncoupling capacity of uncoupler (FCCP) although minocycline added during resting state stimulate the oxygen uptake that might be caused by uncoupling as minocycline is able to decrease the inner membrane potential. However, the uncoupling effect is rather week when compared to that of FCCP. The apparent contradictory effects of minocycline on mitochondrial respiration (i.e., stimulation vs. inhibition) have been, in part, previously reported for others drugs such as local anaesthetics [50]. Since activation of NMDA receptors responsible for excitotoxicity imposes a high energetic demand on the in situ mitochondria [51] one could hypothesize that minocycline exerts its neuroprotective effect by affecting bioenergetic functions of mitochondria. Indeed, this effect could be responsible for the recent report showing that minocycline has a harmful effect on patients with ALS [52]. Accordingly, it was proposed by Kupsch et al. [53] that minocycline impairs mitochondria functions 
Garcia-Martinez EM et al.,

causing $\Delta \psi$ dissipation. Subsequently, deenergized mitochondria lose the ability to undergo $\mathrm{Ca}^{2+}$-triggered MPTP resulting in cell death.

Minocycline might also act as a modulator of the voltage dependent anion channel (VDAC). Minocycline added to a reconstituted system caused VDAC transition into lowerconductance states and decreased the voltage dependence in a concentration-dependent way. Thus, in the presence of minocycline the voltage dependence of reconstituted VDAC is weaker although simultaneously the channel is modified to assume lower conductance states that suggests an effect of minocycline on VDAC gating mechanism [39]. Furthermore flickering of VDAC conductance observed in the presence of minocycline might result from VDAC transient blockade/closure [54]. This, in turn, could have anti-apoptotic effects [19]. Moreover, VDAC closing is accompanied by a change of its selectivity toward cations (e.g. $[38,40])$. However, it has been recently proven that VDAC also has a cation selective open state [55]. Therefore, it was proposed by Mannella and Kinnally [18] that VDAC modulators triggering a transition to lower conductance states might not be acting to close but to open. Nevertheless in the presence of minocycline, the permeability of the mitochondrial outer membrane that is mediated by VDAC might be affected, thus contributing to neuroprotection. In support of this view is the neuroprotective activity of rasagiline, a known anti-Parkinsonian drug, related to its ability to modulate VDAC [56]. Noteworthy, minocycline does not change formation or stability of the planar phospholipid membrane as measured by reconstitution experiments. This implies the absence of nonspecific perturbations of lipid membranes by minocycline. However, it can not be excluded that minocycline acts at the protein-lipid interface causing redistribution of membrane lateral pressure sensed by specific membrane proteins [57].

In conclusion, the results obtained support a pleiotropic mechanism of minocycline neuroprotective activity that involves direct interaction of minocycline with proteins (e.g. 
with VDAC), minocycline-mediated changes in the interface between lipids and membrane proteins (e.g. VDAC, NMDA receptor, complexes of the respiratory chain) and antioxidant effects of minocycline thatcontrol protein activity (e.g. MPTP opening). Although further investigations are required to clarify these mechanisms based in our results (Fig. 11) we can propose that minocycline affects VDAC activity, as well as the mitochondrial respiratory chain at the level of complex I and IV, inhibiting NMDA-induced entry of $\mathrm{Ca}^{2+}$. As a result, minocycline may contribute to change the mitochondrial inner membrane potential, to ROS formation, and to mitochondrial $\mathrm{Ca}^{2+}$ uptake. The effects of minocycline on mitochondria complement its influence on NMDA-mediated $\mathrm{Ca}^{2+}$ influx into the cytosol, as changes in cytosolic $\mathrm{Ca}^{2+}$ concentration may in turn affect mitochondrial respiration, potentially leading to the prevention of NMDA-mediated excitotoxicity that is also conveyed by mitochondria; as lowering of cytosolic $\mathrm{Ca}^{2+}$ concentration inhibits formation and opening of MPTP crucial for apoptotic cell death. Simultaneously, formation and opening of MPTP may be inhibited by minocycline directly and/or indirectly due to its intricate effect on mitochondria. Therefore, under pathological conditions, minocycline may prove beneficial in preventing apoptotic signalling via stabilization of mitochondria-mediated signal cascades.

\section{Acknowledgments}

We are in debit to Ichiro Ikuta and Prof. Pedro Tranque for review and recommendations. Dr. Mercedes Lorenzo and Aymara Valdivia are thanked for their help with catalase and SOD activities experiments. We are grateful to Vanesa Guijarro and Sandra Arteaga for technical assistance and Piotr Bednarczyk for his help. This work was supported 
Garcia-Martinez EM et al.,

by SAF2008-05143-C03-1 from CICYT: Investigación sobre drogodependiencias. Ministerio

de Sanidad y Consumo (04005-00) and PI2007/55 Consejería de Sanidad from Junta de Comunidades de Castilla-La Mancha (to J.J.) and by "CCM Obra Social y Cultural-FISCAM" and "Incorporación de grupos emergentes" FIS CARLOS III (to M.F.G.). RM M-F is a Bellow FPU. S P-A. is a fellow from the Spanish Ministerio de Sanidad y Consumo. SAF2008-05143-C03-2 to NA. MJ J thanks financial support from the European Social Fund. 


\section{REFERENCES}

[1] Blum D, Chtarto A, Tenenbaum L, Brotchi J, Levivier M. Clinical potential of minocycline for neurodegenerative disorders. Neurobiol Dis 2004;17:359-66.

[2] Jordan J, Fernandez-Gomez FJ, Ramos M, Ikuta I, Aguirre N, Galindo MF. Minocycline and cytoprotection: shedding new light on a shadowy controversy. Curr Drug Deliv 2007;4:225-31.

[3] Kim HS, Suh YH. Minocycline and neurodegenerative diseases. Behav Brain Res 2009;196:168-79.

[4] Mievis S, Levivier M, Communi D, Vassart G, Brotchi J, Ledent C, et al. Lack of minocycline efficiency in genetic models of Huntington's disease. Neuromolecular Med 2007;9:47-54.

[5] Goni-Allo B, Ramos M, Jordan J, Aguirre N. In vivo studies on the protective role of minocycline against excitotoxicity caused by malonate or N-methyl-d-aspartate. Exp Neurol 2005;191:326-30.

[6] Chalmers S, Nicholls DG. The relationship between free and total calcium concentrations in the matrix of liver and brain mitochondria. J Biol Chem 2003;278:19062-70.

[7] White RJ, Reynolds IJ. Mitochondria accumulate Ca2+ following intense glutamate stimulation of cultured rat forebrain neurones. J Physiol 1997;498 ( Pt 1):31-47.

[8] Votyakova TV, Reynolds IJ. DeltaPsi(m)-Dependent and -independent production of reactive oxygen species by rat brain mitochondria. J Neurochem 2001;79:266-77.

[9] Pivovarova NB, Nguyen HV, Winters CA, Brantner CA, Smith CL, Andrews SB. Excitotoxic calcium overload in a subpopulation of mitochondria triggers delayed death in hippocampal neurons. J Neurosci 2004;24:5611-22.

[10] Lafon-Cazal M, Pietri S, Culcasi M, Bockaert J. NMDA-dependent superoxide production and neurotoxicity. Nature 1993;364:535-7.

[11] Reynolds IJ, Hastings TG. Glutamate induces the production of reactive oxygen species in cultured forebrain neurons following NMDA receptor activation. J Neurosci 1995;15:3318-27.

[12] Stout AK, Raphael HM, Kanterewicz BI, Klann E, Reynolds IJ. Glutamate-induced neuron death requires mitochondrial calcium uptake. Nat Neurosci 1998;1:366-73.

[13] Kristian T, Siesjo BK. Calcium in ischemic cell death. Stroke 1998;29:705-18.

[14] Zaidan E, Sims NR. The calcium content of mitochondria from brain subregions following short-term forebrain ischemia and recirculation in the rat. $\mathrm{J}$ Neurochem 1994;63:1812-9.

[15] Norenberg MD, Rao KV. The mitochondrial permeability transition in neurologic disease. Neurochem Int 2007;50:983-97.

[16] Bernardi P, Scorrano L, Colonna R, Petronilli V, Di Lisa F. Mitochondria and cell death. Mechanistic aspects and methodological issues. Eur J Biochem 1999;264:687701.

[17] Lemasters JJ, Holmuhamedov E. Voltage-dependent anion channel (VDAC) as mitochondrial governator--thinking outside the box. Biochim Biophys Acta 2006;1762:181-90.

[18] Mannella CA, Kinnally KW. Reflections on VDAC as a voltage-gated channel and a mitochondrial regulator. J Bioenerg Biomembr 2008;40:149-55.

[19] Kroemer G, Galluzzi L, Brenner C. Mitochondrial membrane permeabilization in cell death. Physiol Rev 2007;87:99-163.

[20] Rostovtseva TK, Bezrukov SM. VDAC regulation: role of cytosolic proteins and mitochondrial lipids. J Bioenerg Biomembr 2008;40:163-70. 
[21] Tikka TM, Koistinaho JE. Minocycline provides neuroprotection against N-methyl-Daspartate neurotoxicity by inhibiting microglia. J Immunol 2001;166:7527-33.

[22] Fernandez-Gomez FJ, Gomez-Lazaro M, Pastor D, Calvo S, Aguirre N, Galindo MF, et al. Minocycline fails to protect cerebellar granular cell cultures against malonateinduced cell death. Neurobiol Dis 2005;20:384-91.

[23] Nunez L, Senovilla L, Sanz-Blasco S, Chamero P, Alonso MT, Villalobos C, et al. Bioluminescence imaging of mitochondrial $\mathrm{Ca} 2+$ dynamics in soma and neurites of individual adult mouse sympathetic neurons. J Physiol 2007;580:385-95.

[24] Rogers KL, Stinnakre J, Agulhon C, Jublot D, Shorte SL, Kremer EJ, et al. Visualization of local $\mathrm{Ca} 2+$ dynamics with genetically encoded bioluminescent reporters. Eur J Neurosci 2005;21:597-610.

[25] Voronina SG, Barrow SL, Gerasimenko OV, Petersen OH, Tepikin AV. Effects of secretagogues and bile acids on mitochondrial membrane potential of pancreatic acinar cells: comparison of different modes of evaluating DeltaPsim. J Biol Chem 2004;279:27327-38.

[26] Nunez L, Valero RA, Senovilla L, Sanz-Blasco S, Garcia-Sancho J, Villalobos C. Cell proliferation depends on mitochondrial $\mathrm{Ca} 2+$ uptake: inhibition by salicylate. $\mathrm{J}$ Physiol 2006;571:57-73.

[27] Bindokas VP, Jordan J, Lee CC, Miller RJ. Superoxide production in rat hippocampal neurons: selective imaging with hydroethidine. J Neurosci 1996;16:1324-36.

[28] Navarro A, Boveris A. Rat brain and liver mitochondria develop oxidative stress and lose enzymatic activities on aging. Am J Physiol Regul Integr Comp Physiol 2004;287:R1244-9.

[29] Navarro A, Gomez C, Lopez-Cepero JM, Boveris A. Beneficial effects of moderate exercise on mice aging: survival, behavior, oxidative stress, and mitochondrial electron transfer. Am J Physiol Regul Integr Comp Physiol 2004;286:R505-11.

[30] Brand-Williams W, Cuvelier, M.E. Berset, C. Use of free radical method to evaluate antioxidant activity., 1995.

[31] Benzie IF, Strain JJ. The ferric reducing ability of plasma (FRAP) as a measure of "antioxidant power": the FRAP assay. Anal Biochem 1996;239:70-6.

[32] Schein SJ, Colombini M, Finkelstein A. Reconstitution in planar lipid bilayers of a voltage-dependent anion-selective channel obtained from paramecium mitochondria. J Membr Biol 1976;30:99-120.

[33] Daum G, Gasser SM, Schatz G. Import of proteins into mitochondria. Energydependent, two-step processing of the intermembrane space enzyme cytochrome b2 by isolated yeast mitochondria. J Biol Chem 1982;257:13075-80.

[34] de Pinto V, Prezioso G, Palmieri F. A simple and rapid method for the purification of the mitochondrial porin from mammalian tissues. Biochim Biophys Acta 1987;905:499-502.

[35] Gonzalez JC, Egea J, Del Carmen Godino M, Fernandez-Gomez FJ, Sanchez-Prieto J, Gandia L, et al. Neuroprotectant minocycline depresses glutamatergic neurotransmission and $\mathrm{Ca}(2+)$ signalling in hippocampal neurons. Eur J Neurosci 2007;26:2481-95.

[36] Dykens JA, Stern A, Trenkner E. Mechanism of kainate toxicity to cerebellar neurons in vitro is analogous to reperfusion tissue injury. J Neurochem 1987;49:1222-8.

[37] Morimoto N, Shimazawa M, Yamashima T, Nagai H, Hara H. Minocycline inhibits oxidative stress and decreases in vitro and in vivo ischemic neuronal damage. Brain Res 2005;1044:8-15.

[38] Colombini M, Blachly-Dyson E, Forte M. VDAC, a channel in the outer mitochondrial membrane. Ion Channels 1996;4:169-202. 
[39] Karachitos A, Galganska H, Wojtkowska M, Budzinska M, Stobienia O, Bartosz G, et al. $\mathrm{Cu}, \mathrm{Zn}$-superoxide dismutase is necessary for proper function of VDAC in Saccharomyces cerevisiae cells. FEBS Lett 2009;583:449-55.

[40] Benz R. Permeation of hydrophilic solutes through mitochondrial outer membranes: review on mitochondrial porins. Biochim Biophys Acta 1994;1197:167-96.

[41] Blachly-Dyson E, Song J, Wolfgang WJ, Colombini M, Forte M. Multicopy suppressors of phenotypes resulting from the absence of yeast VDAC encode a VDAC-like protein. Mol Cell Biol 1997;17:5727-38.

[42] Liu MY, Colombini M. A soluble mitochondrial protein increases the voltage dependence of the mitochondrial channel, VDAC. J Bioenerg Biomembr 1992;24:416.

[43] Fernandez-Gomez FJ, Galindo MF, Gomez-Lazaro M, Gonzalez-Garcia C, Cena V, Aguirre $\mathrm{N}$, et al. Involvement of mitochondrial potential and calcium buffering capacity in minocycline cytoprotective actions. Neuroscience 2005;133:959-67.

[44] Tikka T, Fiebich BL, Goldsteins G, Keinanen R, Koistinaho J. Minocycline, a tetracycline derivative, is neuroprotective against excitotoxicity by inhibiting activation and proliferation of microglia. J Neurosci 2001;21:2580-8.

[45] Pi R, Li W, Lee NT, Chan HH, Pu Y, Chan LN, et al. Minocycline prevents glutamate-induced apoptosis of cerebellar granule neurons by differential regulation of p38 and Akt pathways. J Neurochem 2004;91:1219-30.

[46] Hua XY, Svensson CI, Matsui T, Fitzsimmons B, Yaksh TL, Webb M. Intrathecal minocycline attenuates peripheral inflammation-induced hyperalgesia by inhibiting p38 MAPK in spinal microglia. Eur J Neurosci 2005;22:2431-40.

[47] Lampl Y, Boaz M, Gilad R, Lorberboym M, Dabby R, Rapoport A, et al. Minocycline treatment in acute stroke: an open-label, evaluator-blinded study. Neurology 2007;69:1404-10.

[48] Kraus RL, Pasieczny R, Lariosa-Willingham K, Turner MS, Jiang A, Trauger JW. Antioxidant properties of minocycline: neuroprotection in an oxidative stress assay and direct radical-scavenging activity. J Neurochem 2005;94:819-27.

[49] Nicholls DG FS. Bioenergetics 3. London: Academic Press, 2002.

[50] Sun X, Garlid KD. On the mechanism by which bupivacaine conducts protons across the membranes of mitochondria and liposomes. J Biol Chem 1992;267:19147-54.

[51] Yadava N, Nicholls DG. Spare respiratory capacity rather than oxidative stress regulates glutamate excitotoxicity after partial respiratory inhibition of mitochondrial complex I with rotenone. J Neurosci 2007;27:7310-7.

[52] Gordon PH, Moore DH, Miller RG, Florence JM, Verheijde JL, Doorish C, et al. Efficacy of minocycline in patients with amyotrophic lateral sclerosis: a phase III randomised trial. Lancet Neurol 2007;6:1045-53.

[53] Kupsch K, Hertel S, Kreutzmann P, Wolf G, Wallesch CW, Siemen D, et al. Impairment of mitochondrial function by minocycline. FEBS J 2009;276:1729-38.

[54] Tan W, Loke YH, Stein CA, Miller P, Colombini M. Phosphorothioate oligonucleotides block the VDAC channel. Biophys J 2007;93:1184-91.

[55] Pavlov E, Grigoriev SM, Dejean LM, Zweihorn CL, Mannella CA, Kinnally KW. The mitochondrial channel VDAC has a cation-selective open state. Biochim Biophys Acta 2005;1710:96-102.

[56] Youdim MB, Weinstock M. Molecular basis of neuroprotective activities of rasagiline and the anti-Alzheimer drug TV3326 [(N-propargyl-(3R)aminoindan-5-YL)-ethyl methyl carbamate]. Cell Mol Neurobiol 2001;21:555-73.

[57] Cantor RS. The lateral pressure profile in membranes: a physical mechanism of general anesthesia. Biochemistry 1997;36:2339-44. 


\section{Figure legends}

Figure 1. Minocycline protects neuronal cultures against excitotoxic stimulus in a concentration-dependent manner. After 7 days in vitro, cultured cerebellar granule cells were exposed to $100 \mu \mathrm{M}$ NMDA for $30 \mathrm{~min}$. Minocycline $(10-150 \mu \mathrm{M})$ was added $10 \mathrm{~min}$ before exposure to NMDA and maintained until the end of experiment. Cell viability was assayed $24 \mathrm{~h}$ later. Black bars in this figure represent treatment with the indicated minocycline concentrations in the absence of NMDA. The data represent mean \pm SD of at least 9 coverslips (three independent cell cultures). ${ }^{*} \mathrm{p}<0.01$ different from 0 minocycline and NMDA (analysis of the variance and Tukey test).

Figure 2. Minocycline inhibits the increases in cytosolic and mitochondrial $\left[\mathrm{Ca}^{2+}\right]$ induced by NMDA. A. Cerebellar granule cells were loaded with fura2/AM and $\left[\mathrm{Ca}^{2+}\right]_{\mathrm{cyt}}$ levels were monitored by fluorescence microscopy. Pictures show $\left[\mathrm{Ca}^{2+}\right]_{\text {cyt }}$ levels (coded in pseudocolor, color scale, 0 to $2500 \mathrm{nM})$ during perfusion with NMDA (100 $\mu \mathrm{M})$ with and without minocycline $(100 \mu \mathrm{M})$. Traces show recordings of $\left[\mathrm{Ca}^{2+}\right]_{\mathrm{cyt}}$ in individual, representative cerebellar granule cells. ( $n=193$ cells, 4 independent experiments). B. Cerebellar granule cells were transfected with GA plasmid. 24 h later were incubated with coelenterazine for $2 \mathrm{~h}$ at room temperature and subjected to $\left[\mathrm{Ca}^{2+}\right]_{\text {mit }}$ measurements by photon counting imaging. Pictures show the bioluminescence (AEQ) and fluorescence (GFP) images of transfected cells. Color scale 0 to 100 photonic emissions per pixel. Traces show recordings of $\left[\mathrm{Ca}^{2+}\right]_{\text {mit }}$ in individual, representative cerebellar granule cells $(\mathrm{n}=11$ cells, 2 independent experiments). 
Figure 3. Minocycline decreases cytosolic $\mathrm{Ca}^{2+}$ levels when added in the presence of NMDA but not in the presence of high $\mathrm{K}^{+}$medium. Cerebellar granule cells were loaded with fura2/AM and $\left[\mathrm{Ca}^{2+}\right]_{\mathrm{cyt}}$ levels were monitored by fluorescence microscopy. Traces show the effect of minocycline $(100 \mu \mathrm{M})$ over the increased $\left[\mathrm{Ca}^{2+}\right]_{\text {cyt }}$ induced by NMDA $(100 \mu \mathrm{M})$ (A) or high $\mathrm{K}^{+}$(B) medium. Traces are mean \pm SEM values of $\left[\mathrm{Ca}^{2+}\right]_{\mathrm{cyt}}$ on all cells present in the same microscopic field and are representative of at least 3 independent experiments.

Figure 4. Minocycline depolarizes mitochondria and inhibits mitochondrial $\mathrm{Ca}^{2+}$ uptake. A. Cerebellar granule cells were loaded with $10 \mathrm{nM}$ TMRM for monitoring the effects of minocycline on the mitochondrial inner membrane potential. Pictures show TMRM staining of the same cells before and after treatment with 10 and $100 \mu \mathrm{M}$ minocycline $\mu \mathrm{M}$ and $10 \mu \mathrm{M}$ FCCP. Traces show average recordings of TMRM fluorescence in representative experiments. Fluorescence values were normalized to the value before treatment and averaged ( $\mathrm{n}=50$ cells, 3 experiments). B. Cerebellar granule cells were transfected with GA plasmid, cultured for $24 \mathrm{~h}$ and incubated with coelenterazine for $2 \mathrm{~h}$ at room temperature. Cells were permeabilized by digitonin in intracellular medium (see methods) and subjected to bioluminescence imaging of mitochondrial $\left[\mathrm{Ca}^{2+}\right]$. Permeabilized cells were stimulated with intracellular medium containing $10 \mu \mathrm{M}\left[\mathrm{Ca}^{2+}\right]$ in the presence of $100 \mu \mathrm{M}$ minocycline and after its removal. Traces shown are recordings from representative, individual cells ( $\mathrm{n}=36$ cells, 6 independent experiments).

Figure 5. Minocycline presents anti-oxidant functions. A. Minocycline declines intracellular superoxide production rate induced by NDMA $(100 \mu \mathrm{M})$ in cerebellar granular cells. The slopes of the lines fitting the fluorescence intensity changes (an index of the rate of superoxide production) were individually measured and averaged. At least 84 individual cells 
Garcia-Martinez EM et al.,

were averaged to calculate the slope. The mean slope values were used to generate a theoretical line using the following equation: $y=a x$. The figure represents generated lines of $\mathrm{O}_{2}^{-}$production in both basal conditions and during $100 \mu \mathrm{M}$ NMDA with and without minocycline $(1,10,50,100 \mu \mathrm{M})$. B. Minocycline abrogates ROS production caused by $75 \mu \mathrm{M}$ $\mathrm{Ca}^{2+}$ in brain isolated mitochondria. DFCA fluorescence was measured 30 min after the addition of $\mathrm{Ca}^{2+}$ to mitochondrial suspensions. Data are mean $\pm \mathrm{SD}$, of at least 4 different preparations. Columns marked with the same small letters denotes values not significantly different ( $p>0.05)$. C-D. Minocycline showed a DPPH radical scavenger activity (C) and mediates the reduction of $\mathrm{Fe}^{3+}$ to $\mathrm{Fe}^{2+}$ (FRAP) (D). The data represent mean \pm SD of at least 4 or 3 independent experiments. $* \mathrm{p}<0.05 * * p<0.001$ vs control conditions (without minocycline).

Figure 6. Mitochondrial oxygen uptake of rat brain mitochondria in phosphorylating state. Respiratory rates were determined at $30{ }^{\circ} \mathrm{C}$. Additions: mitochondria (0.7-0.8 mg/ml), $5 \mathrm{mM}$ malate- $5 \mathrm{mM}$ glutamate, $6 \mathrm{mM}$ succinate, $0.5 \mathrm{mM}$ ADP and $125 \mu \mathrm{M}$ minocycline. The numbers near the traces indicates oxygen uptake in ng-at $\mathrm{O} / \mathrm{min} \mathrm{x} \mathrm{mg}$ protein.

Figure 7. Mitochondrial oxygen uptake of rat brain mitochondria in resting state and in uncoupled state induced by FCCP. Respiratory rates were determined at $30{ }^{\circ} \mathrm{C}$. Additions: mitochondria $(0.7-0.8 \mathrm{mg} / \mathrm{ml}) 5 \mathrm{mM}$ malate- $5 \mathrm{mM}$ glutamate, $6 \mathrm{mM}$ succinate, 0.1 $\mu \mathrm{M}$ FCCP and $125 \mu \mathrm{M}$ minocycline. The numbers near the traces indicates oxygen uptake in ng-at $\mathrm{O} / \mathrm{min} \mathrm{x}$ mg protein $(\mathrm{n}=3)$. 
Figure 8. Effects of minocycline on the mitochondrial oxygen uptake of rat brain

mitochondria in state 4 , state $3(0.5 \mathrm{mM}$ ADP) and state $3 \mathrm{u}(0.1 \mu \mathrm{M} \mathrm{FCCP})(\mathrm{n}=3)$. Respiratory rates are determined with mitochondria $(0.7-0.8 \mathrm{mg} / \mathrm{ml})$ at $30{ }^{\circ} \mathrm{C}$. Panel A: $5 \mathrm{mM}$ malate, $5 \mathrm{mM}$ glutamate as respiratory substrate; panel B: $10 \mathrm{mM}$ succinate as substrate.

Figure 9. Effects of minocycline on the electron transfer activities of rat brain mitochondrial membranes. NADH-cytochrome c reductase activity (Complexes I-III) and succinate-cytochrome $\mathrm{c}$ reductase activity (Complexes II + III) expressed as nmol cytochrome $c$ reduced/min $\times$ mg protein; and cytochrome oxidase activity (Complex IV) expressed as nmol cytochrome c oxidized at $10 \mu \mathrm{M}$ cytochrome $c / \min \times \operatorname{mg}$ protein. $(\mathrm{n}=3)$.

Figure 10. The effect of minocycline on reconstituted VDAC. (A) Examples of single channel insertions in the presence of increasing minocycline concentrations at a membrane potential of $+10 \mathrm{mV}$. (B) Histograms of VDAC conductances obtained in the presence of increasing minocycline concentrations at a membrane potential of $+10 \mathrm{mV}$. P (G) is the probability that a given conductance increment $G$ is observed. (C) VDAC average conductance as a function of minocycline concentration. Values of average conductance were calculated at a membrane potential of $+10 \mathrm{mV}$. The dominance of VDAC closure at a membrane potential of $+70 \mathrm{mV}$ corresponded to an average conductance of $1.9 \pm 0.2 \mathrm{nS}$. (D) The dependence of VDAC on the applied potential in the presence of minocycline increasing concentrations. $\mathrm{G} / \mathrm{G}_{0}$ is the ratio of the conductance $(\mathrm{G})$ at a given voltage and the conductance $\left(\mathrm{G}_{0}\right)$ at the lowest applied potential $(10 \mathrm{mV})$. The average amount of analysed insertion events for a given conditions used to calculate average conductance was 70 . The obtained values of average conductance were statistically different. 
Figure 11. A model of minocycline-mediated neuroprotection. Minocycline inhibits

$\mathrm{Ca}^{2+}$ entry supported by NMDA receptor being a hallmark of excitotoxicity. In addition, minocycline modulates both VDAC and the respiratory chain (RC) leading to mitochondrial depolarization. Mitochondrial depolarization diminishes the driving force for mitochondrial $\mathrm{Ca}^{2+}$ uptake through the mitochondrial $\mathrm{Ca}^{2+}$ uniporter (MCU), which prevents mitochondrial $\mathrm{Ca}^{2+}$ overload, ROS production and apoptosis execution. These pleiotropic effects may contribute to explain the neuroprotection afforded by minocycline. 


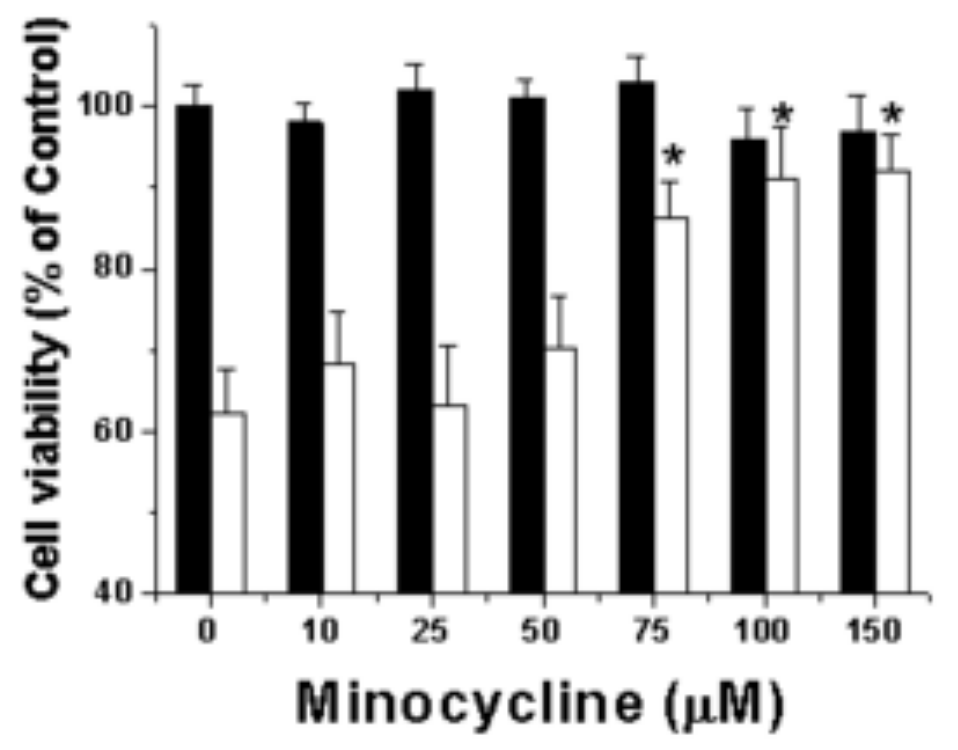



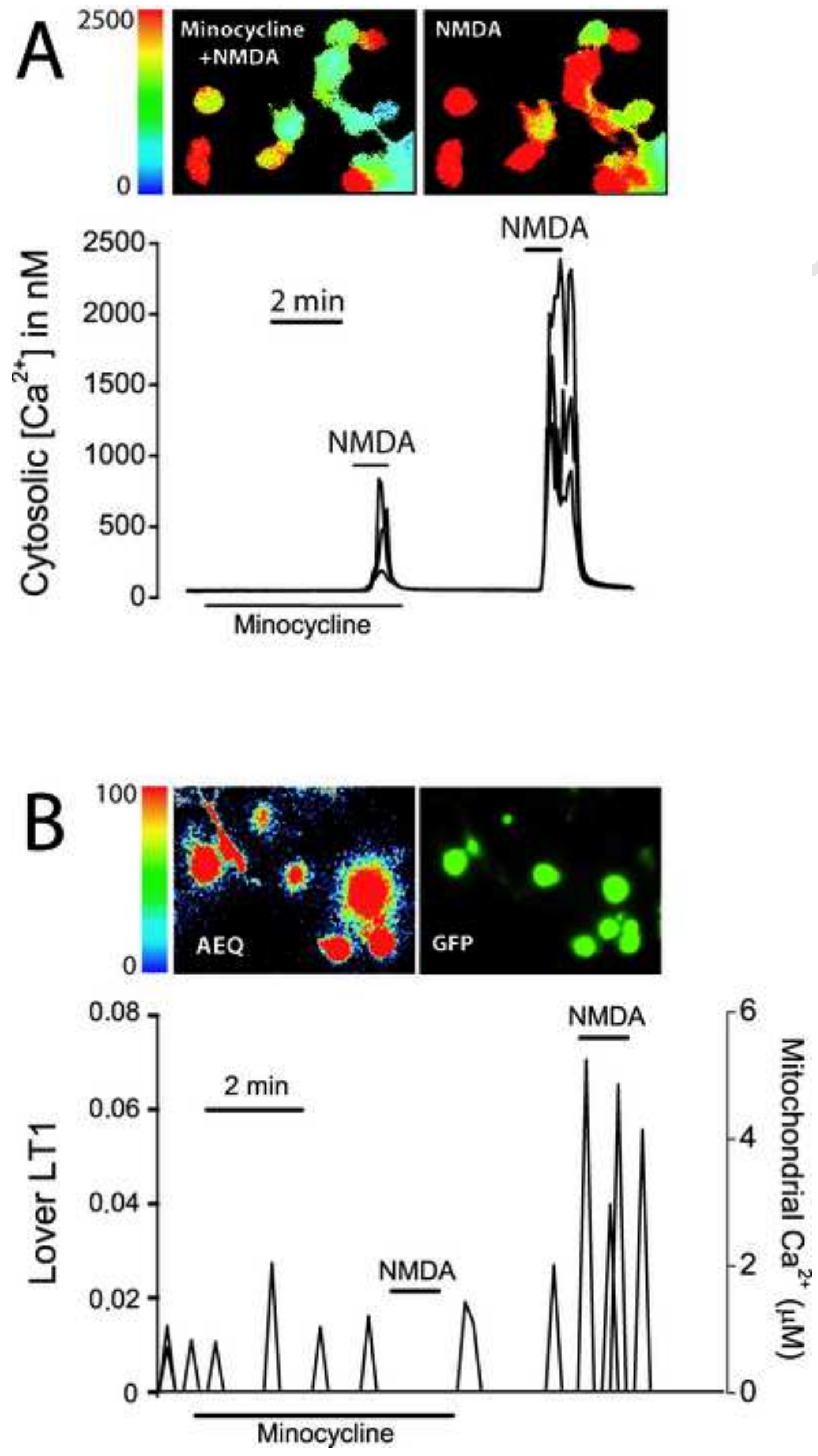

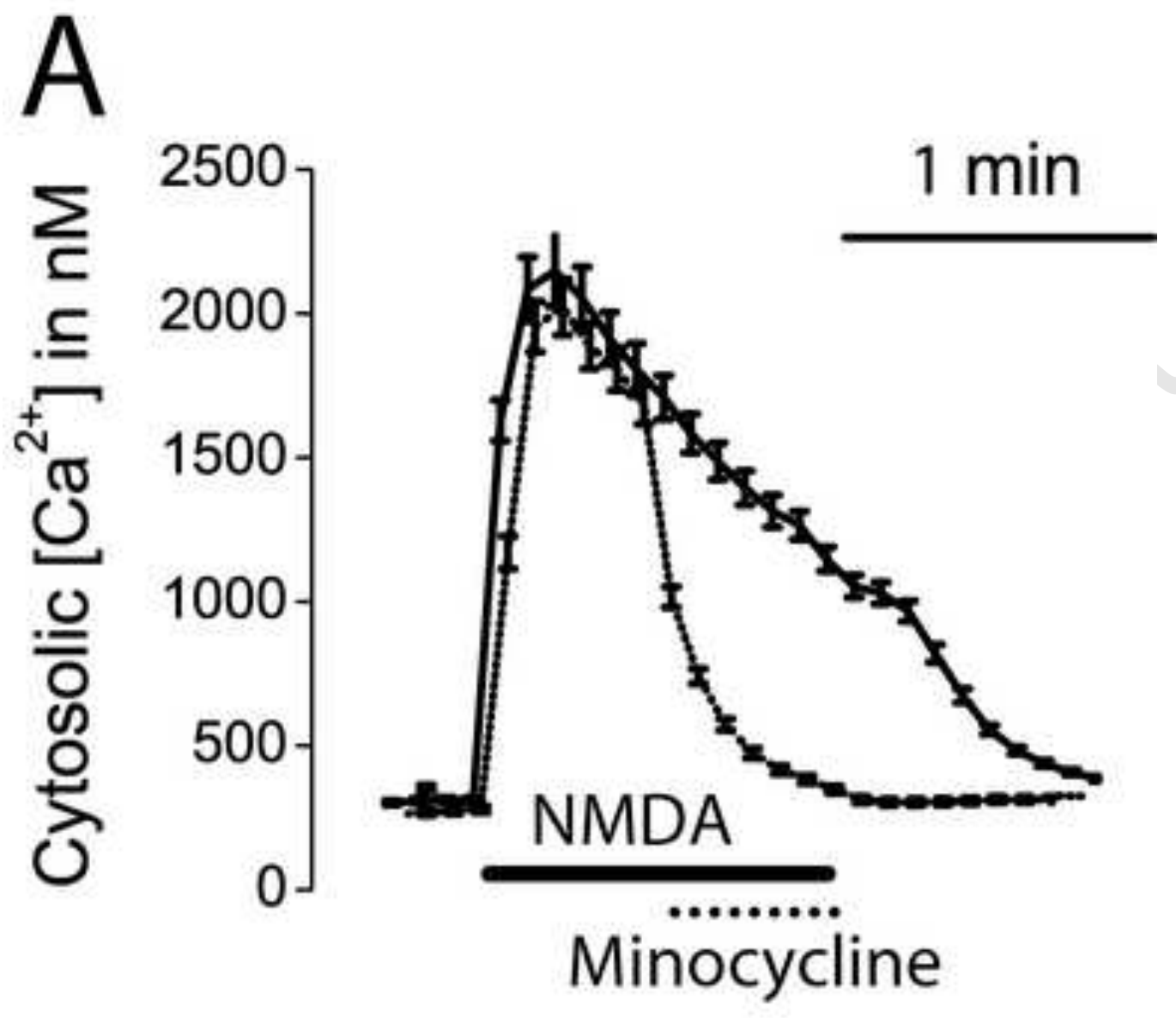

B

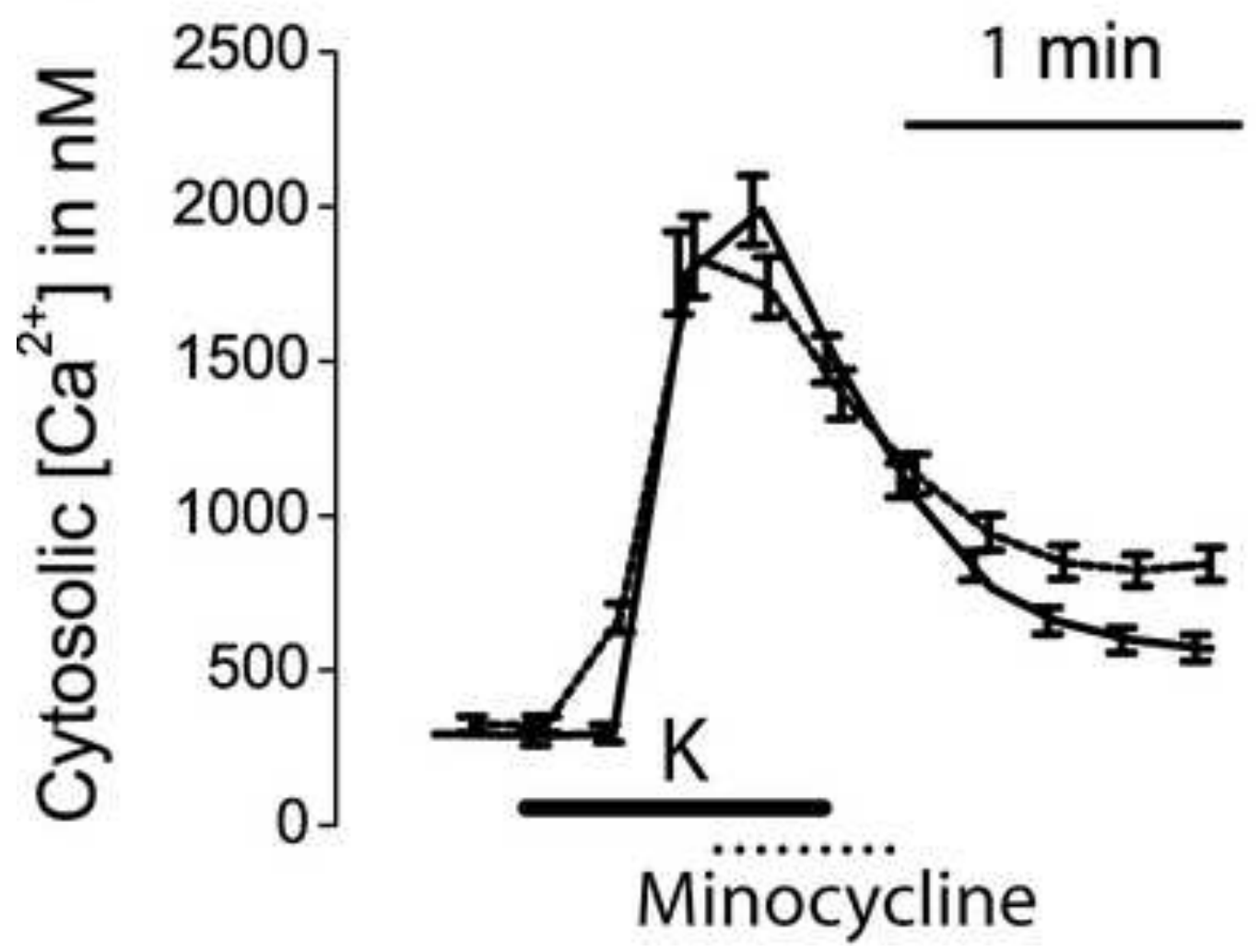


A
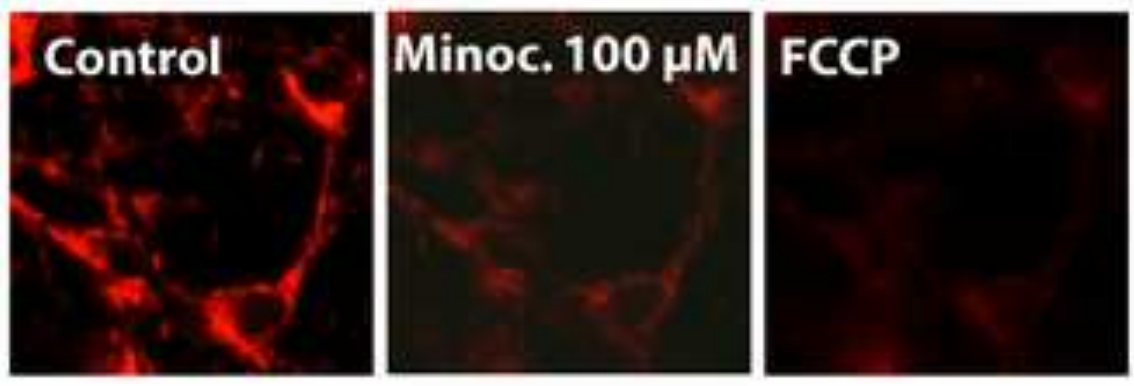

Minocycline

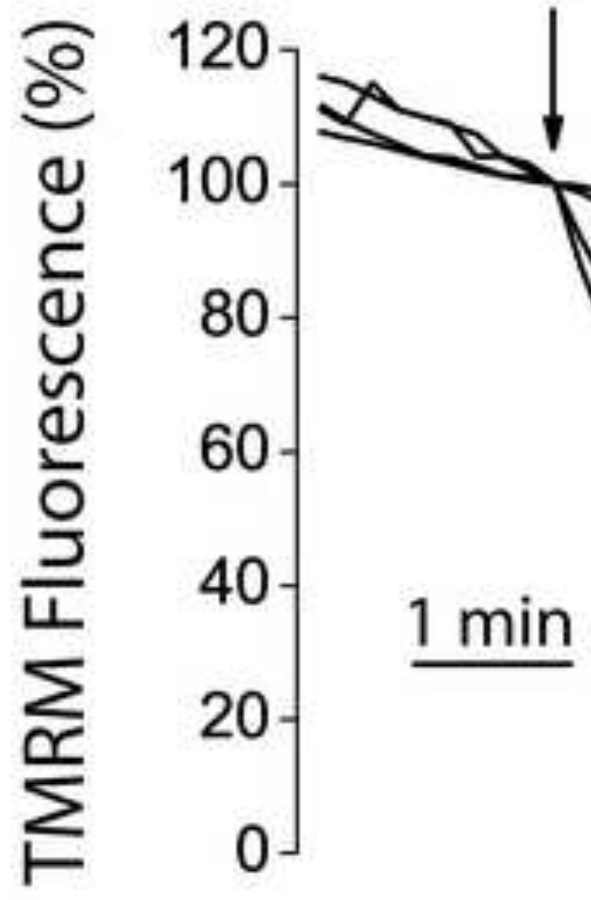

Control $10 \mu \mathrm{M}$
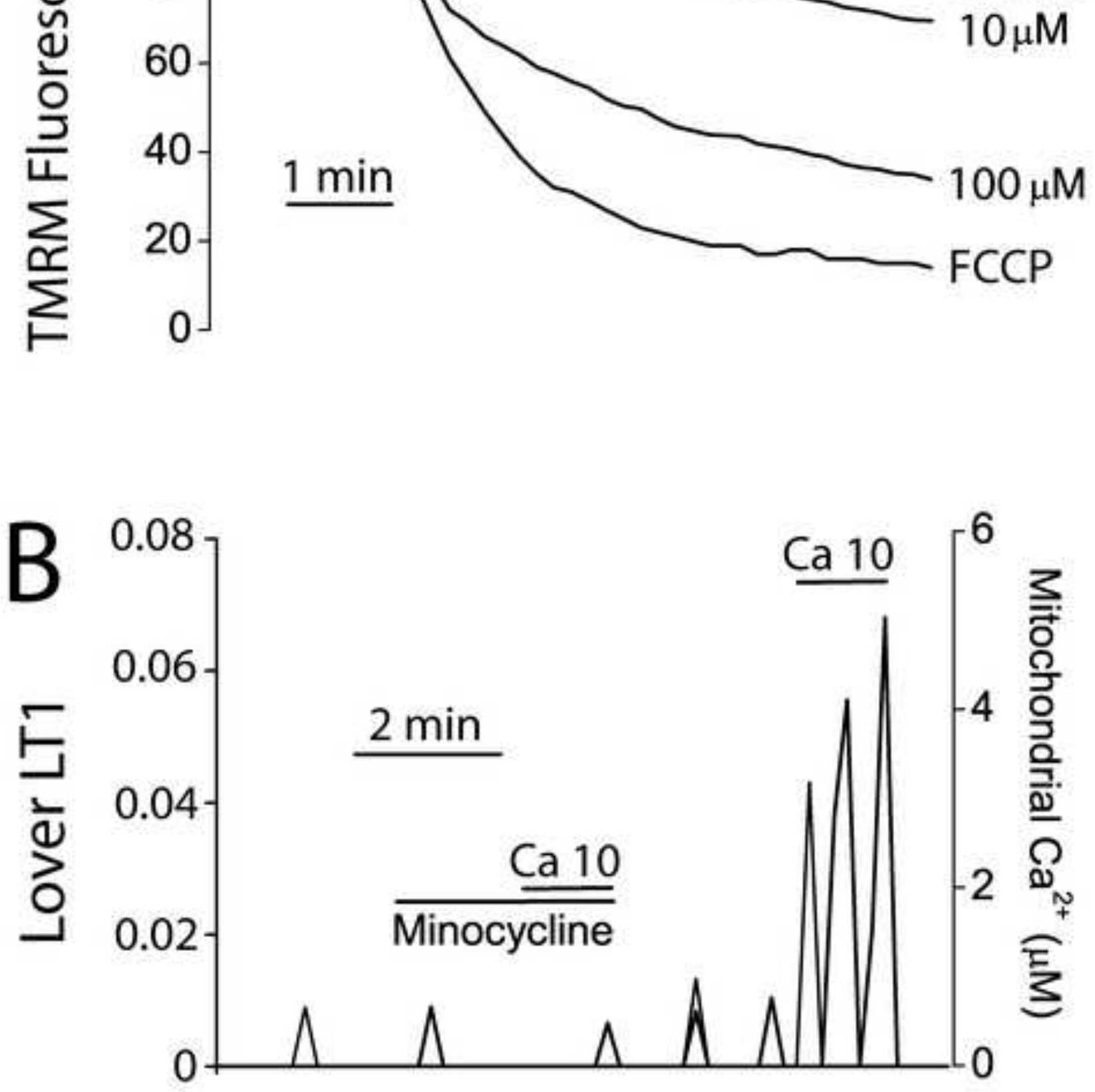
$A$ 을
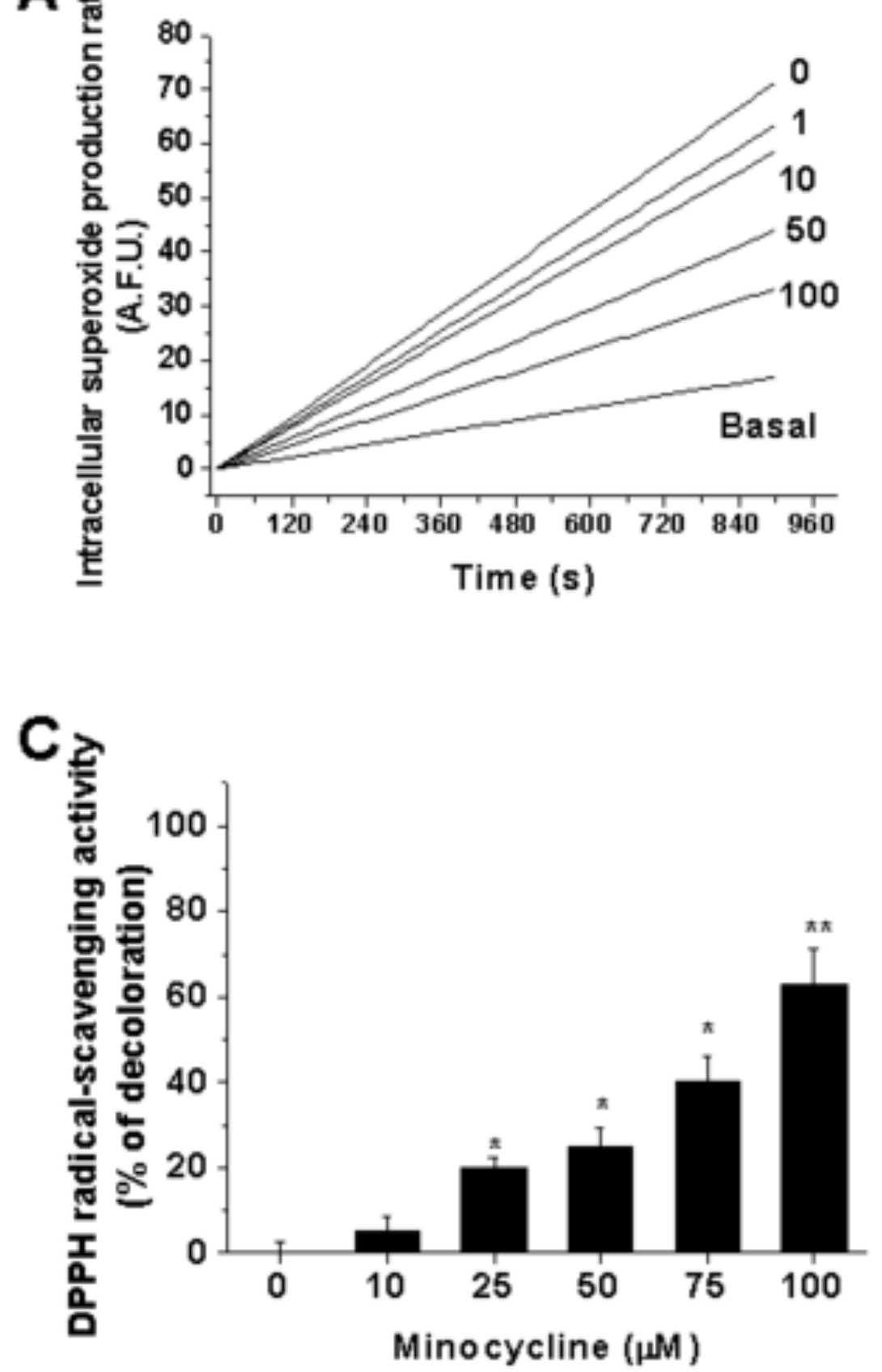

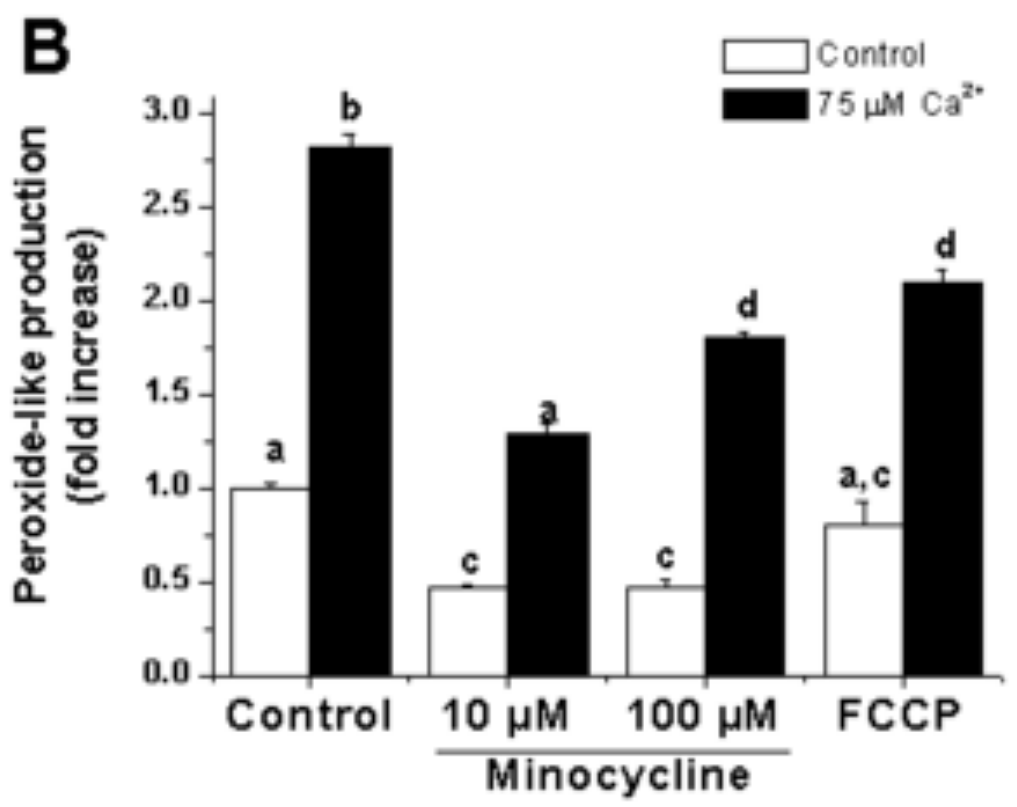

D

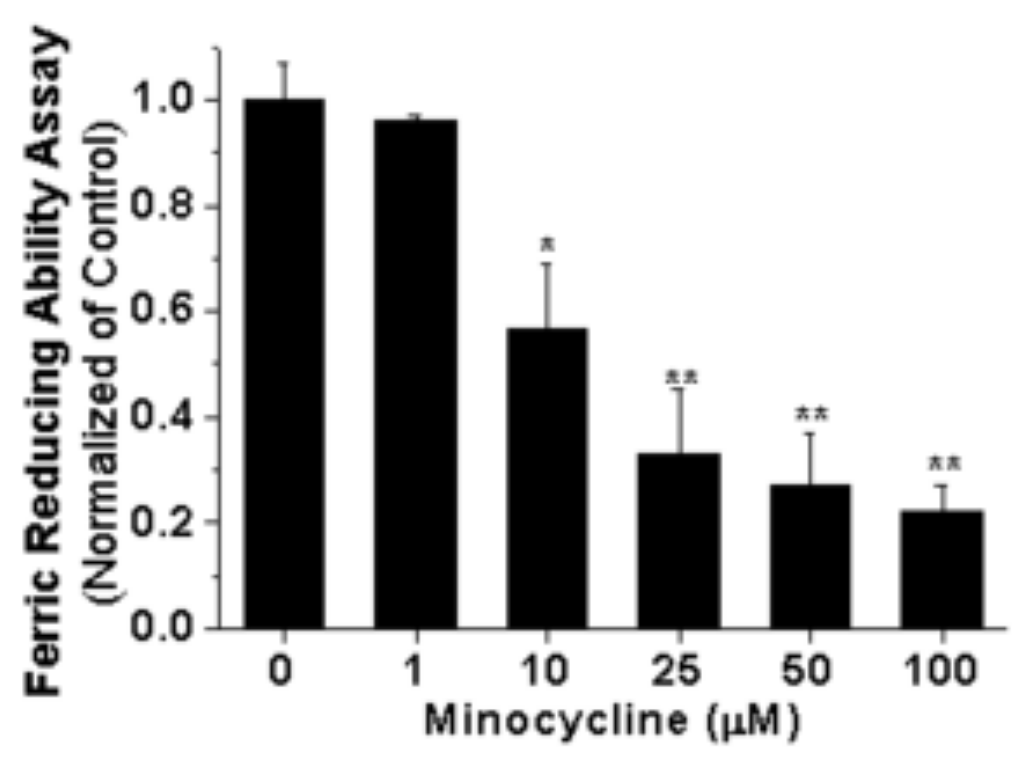



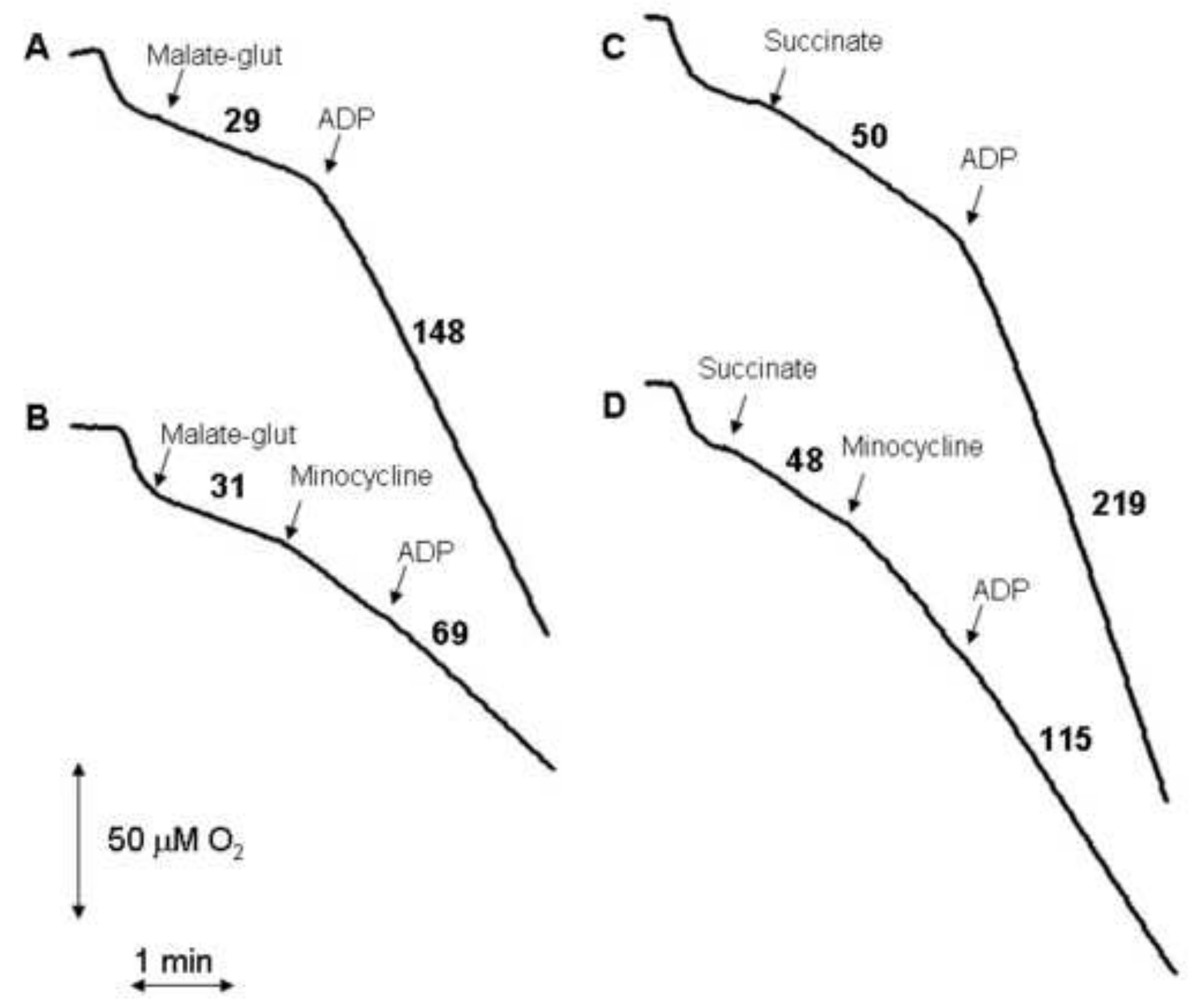

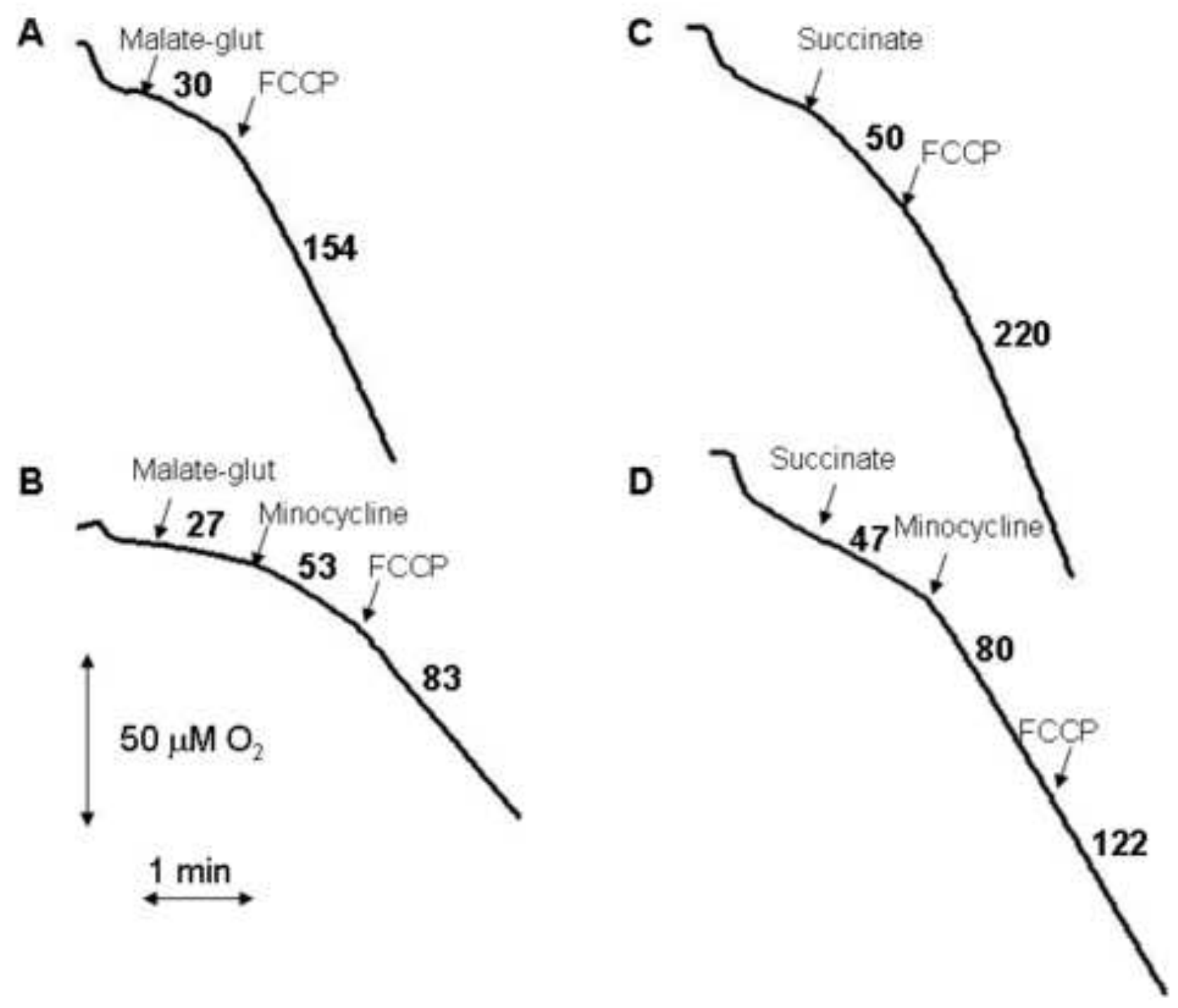

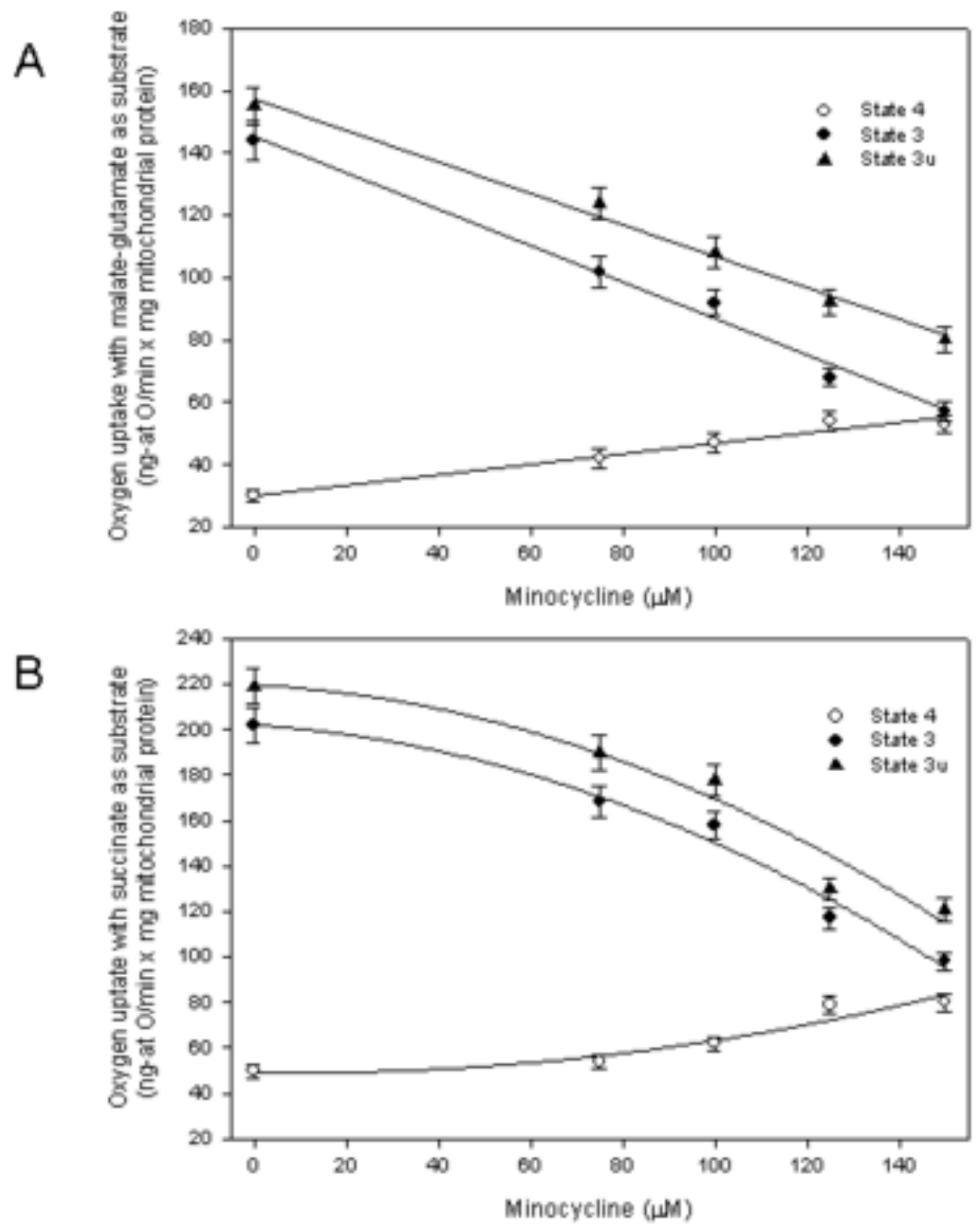

rage 43 or $4 /$ 


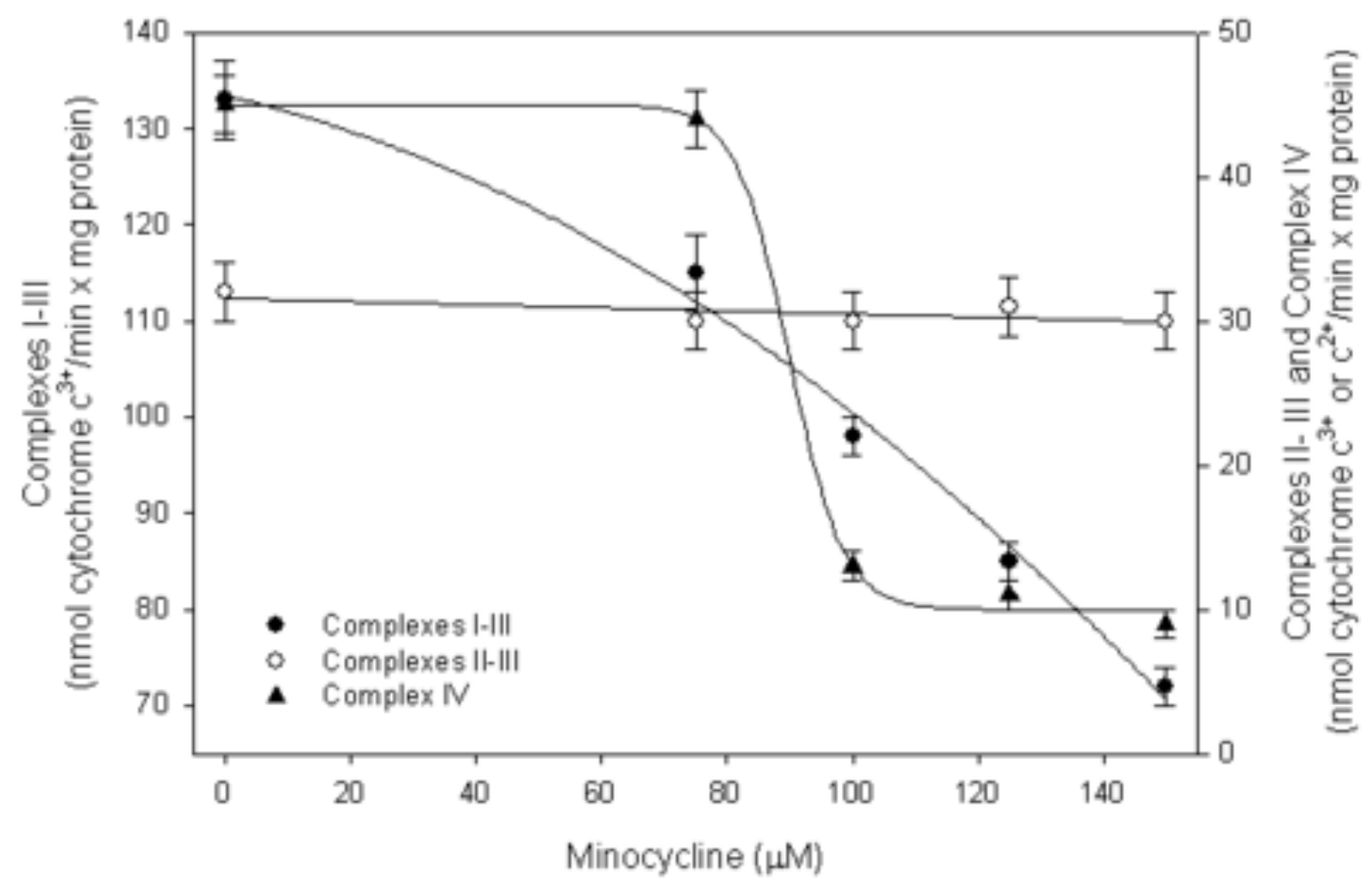

rage 44 or 4 /

\section{Figure}

rage 44 or $4 /$ 
A

Control

Minocycline $50 \mu \mathrm{M}$

Minocycline $100 \mu \mathrm{M}$
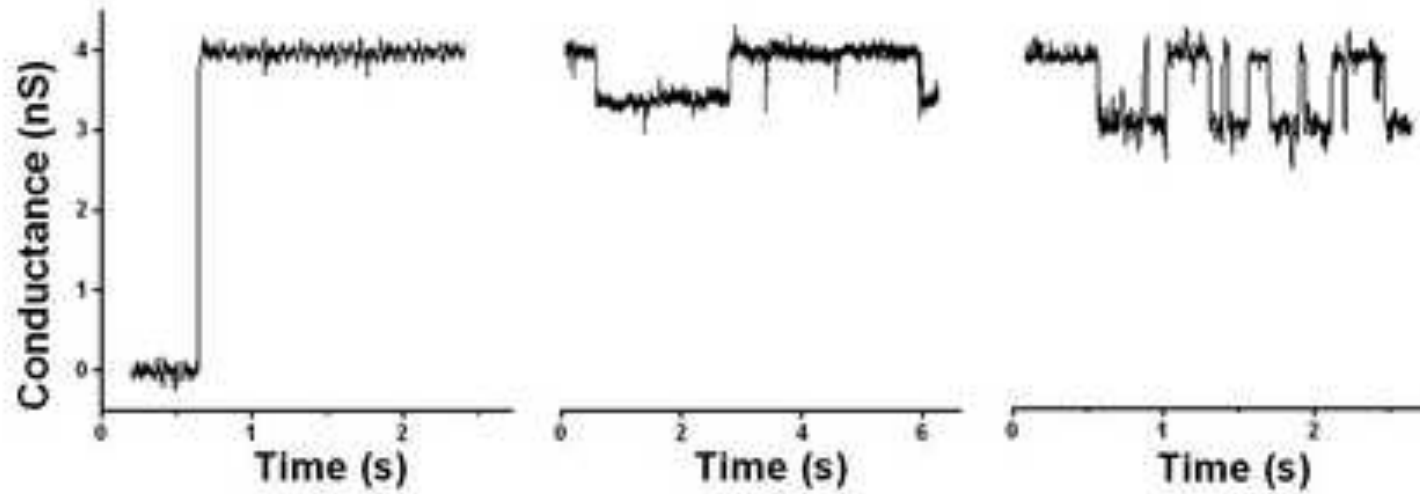

B
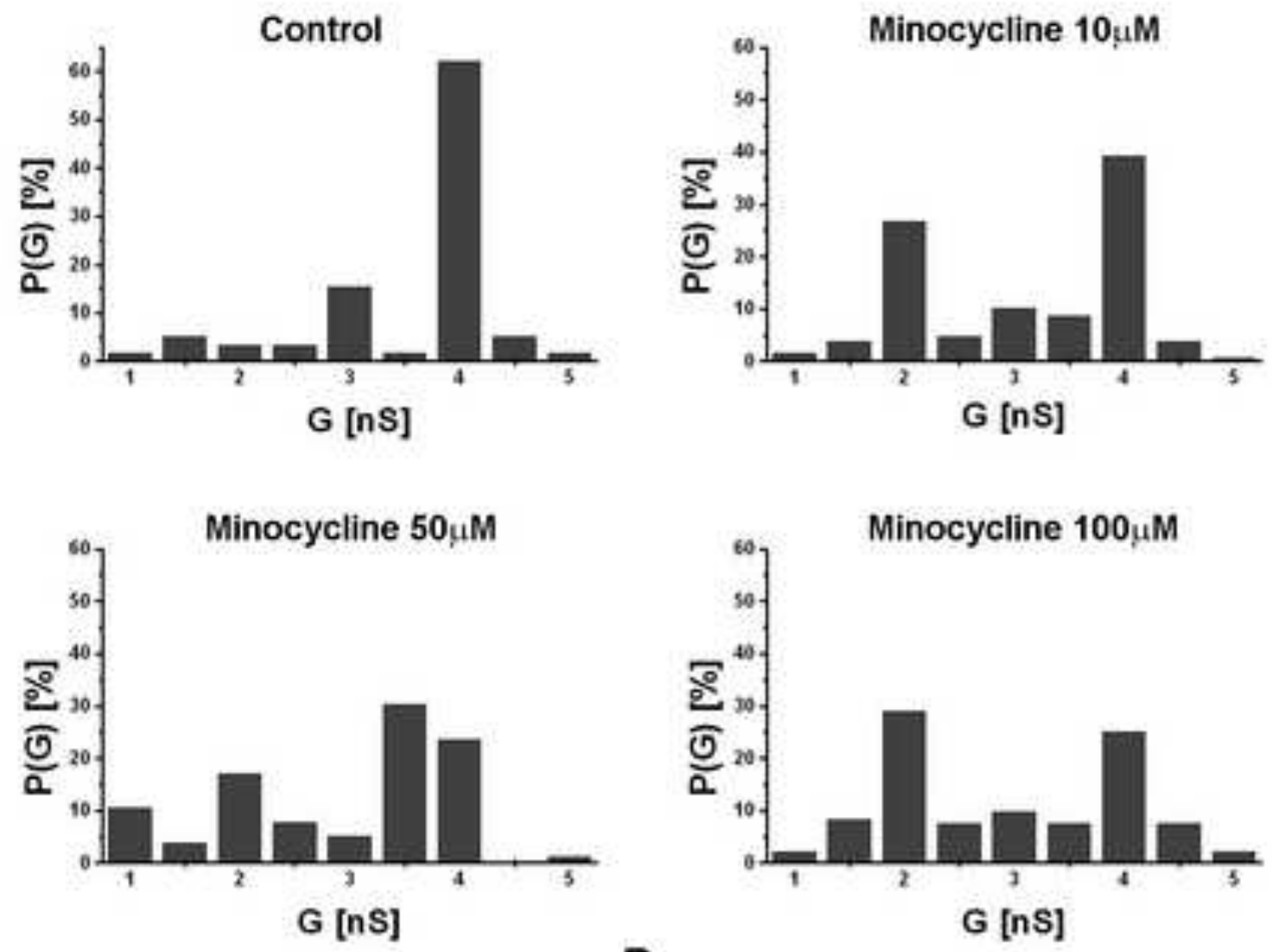

C
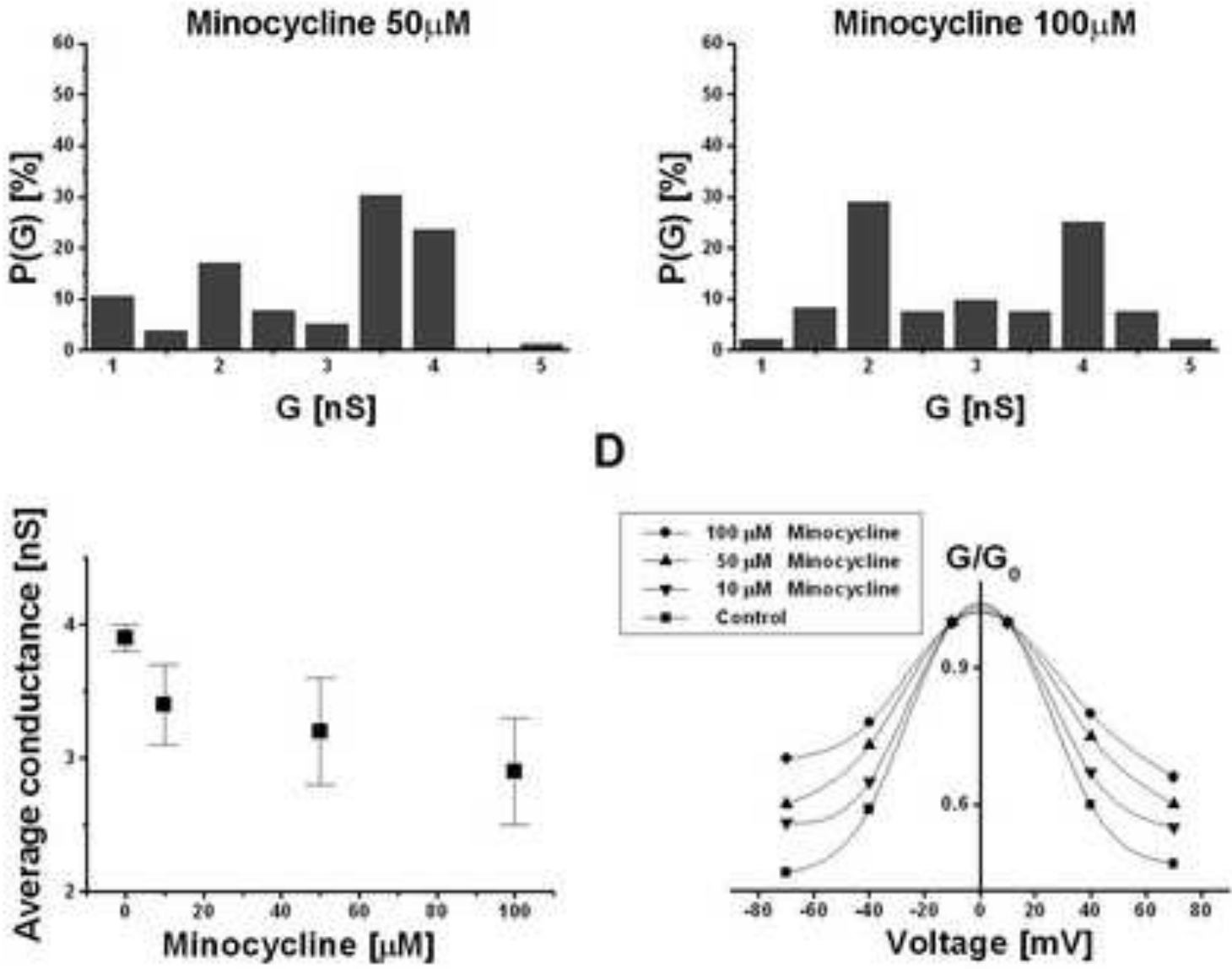


\section{Minocycline}
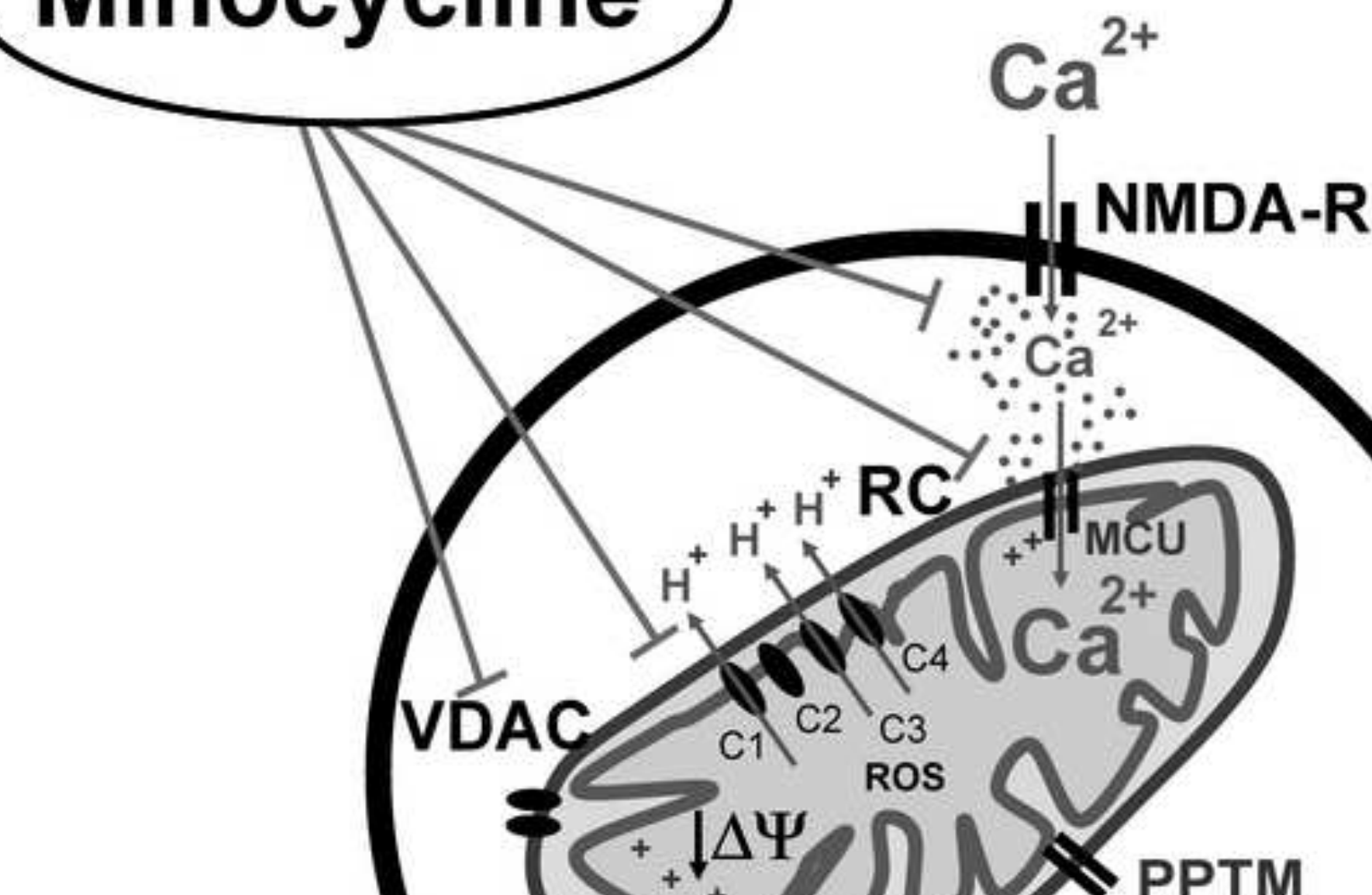

PPTM

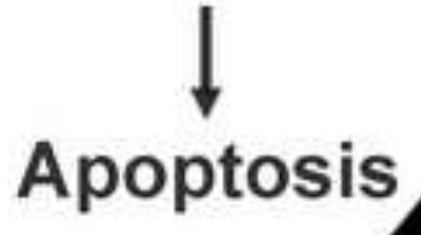




\section{Minocycline}

$\checkmark$

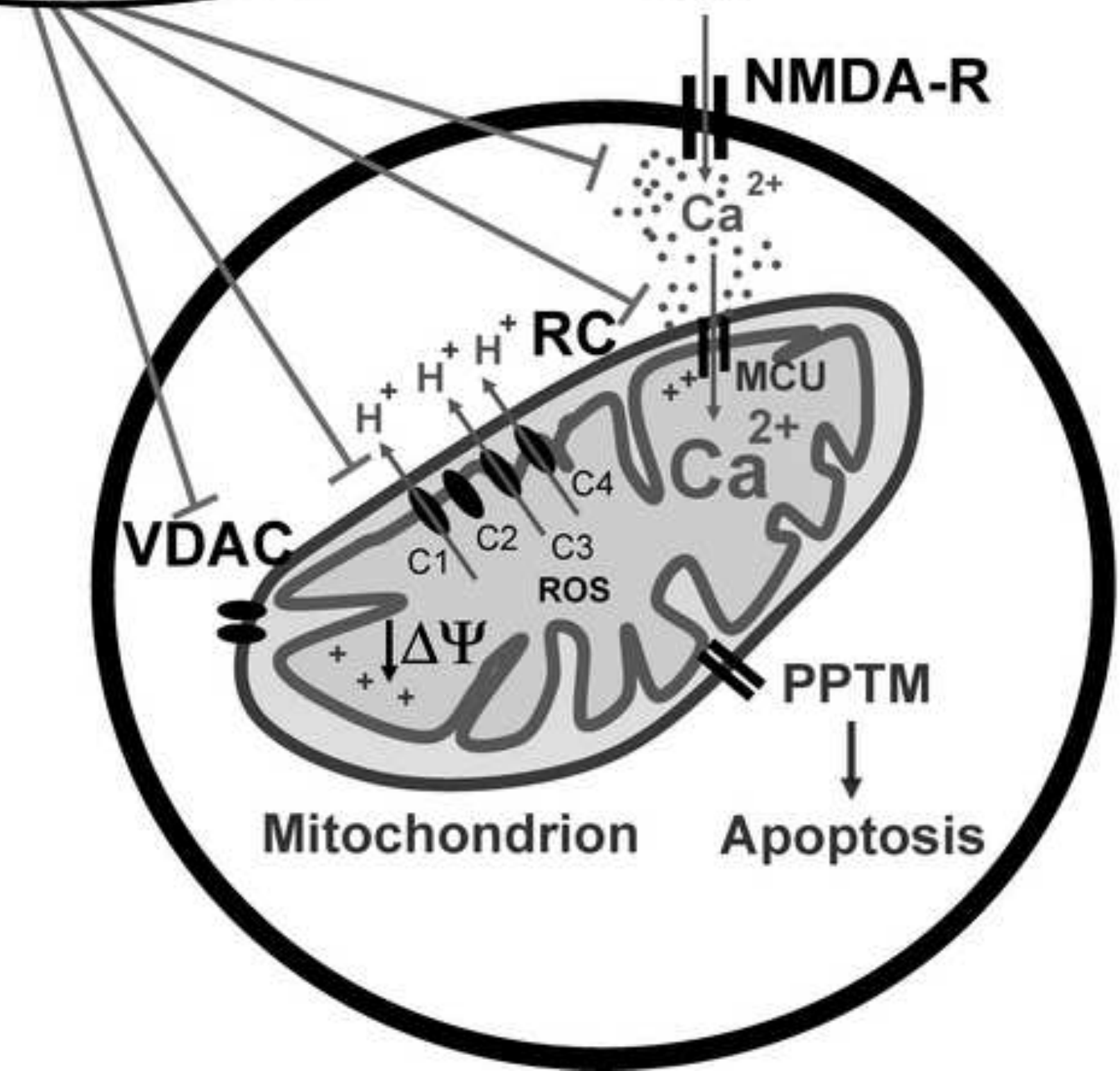

rage 4 / Ot 4 / 